The Canadian Mineralogist

Vol. 39, pp. 421-446 (2001)

\title{
MULTICOMPONENT ELEMENTAL AND ISOTOPIC MIXING IN Ni-Cu-(PGE) ORES AT KAMBALDA, WESTERN AUSTRALIA
}

\author{
C. MICHAEL LESHER ${ }^{\S}$ AND O. MARCUS BURNHAM \\ Mineral Exploration Research Centre and Department of Earth Sciences, Willet Green Miller Mines and \\ Minerals Research Centre, Laurentian University, Sudbury, Ontario P3E 6B5, Canada
}

\begin{abstract}
Most magmatic $\mathrm{Ni}-\mathrm{Cu}-(\mathrm{PGE})$ deposits are considered to have formed from sulfide-undersaturated silicate magmas and to contain a significant component of crustal sulfur that was derived via wholesale melting, partial melting, or devolatilization of wall rocks. Under such circumstances, the system may comprise a silicate magma and a sulfide magma, with or without crystalline solids, undissolved wallrock-derived xenoliths, an unmixed silicate xenomelt, or an undissolved xenovolatile phase, each of which may contain distinct chalcophile and lithophile components. Because traditional two-component (silicate magma - sulfide magma) mass-balance models do not accurately model such systems, we have developed a series of multicomponent elemental and isotopic mass-balance equations to model batch equilibration in magmatic $\mathrm{Ni}-\mathrm{Cu}-(\mathrm{PGE})$ systems. We have applied them to the type examples of komatiite-associated Ni-Cu-(PGE) deposits at Kambalda, Western Australia. The calculations indicate that the elemental and isotopic compositions of the various components in a multicomponent system will vary considerably as a function of the relative abundances of the components, and that different metals and isotopic systems may decouple from each other, yielding apparently conflicting information regarding the sources of the components. The results suggest that the $\mathrm{S}$ isotopic and $\mathrm{Zn}$ compositions of the ores are more sensitive indicators of contamination than the Os isotopes, and support a sedimentmelting model for Kambalda.
\end{abstract}

Keywords: mass balance, mixing, xenolith, xenomelt, xenovolatile, nickel (Ni), copper (Cu), platinum-group elements (PGE), Kambalda, Australia.

\section{SOMMAIRE}

Dans la plupart des cas, les gisements magmatiques de $\mathrm{Ni}-\mathrm{Cu}$-(éléments du groupe du platine, EGP) se seraient formés à partir de magmas silicatés sous-saturés en sulfures; ceux-ci auraient hérité d'une contribution importante de soufre dérivé de la croûte par fusion complète, fusion partielle, ou dévolatilisation de l'encaissant. Dans de telles circonstances, le système pourrait contenir un magma silicaté et un magma sulfuré, avec ou sans phases cristallines, des xénolithes non dissous détachés de l'encaissant, un bain fondu silicaté d'origine externe, ou une phase volatile aussi d'origine externe, chacun pouvant contenir des composants distincts chalcophiles et lithophiles. Les modèles traditionnels de bilans des masses à deux composantes (magma silicaté - magma sulfuré) ne reflètent pas adéquatement de tels systèmes. Nous avons donc dû développer une série d'équations décrivant le bilan des masses d'éléments et d'isotopes dans des systèmes à composantes multiples afin de simuler l'équilibrage de volumes dans des systèmes magmatiques à Ni-Cu-(EGP). Nous les avons appliqué à l'exemple-type de gisements de $\mathrm{Ni}-\mathrm{Cu}-$ (EGP) associés aux venues komatiitiques, à Kambalda, en Australie occidentale. Nos calculs indiquent que les teneurs en éléments et en isotopes des diverses composantes des tels systèmes varient considérablement en fonction de l'abondance relative des composantes, et que les métaux et les systèmes isotopiques peuvent se découpler les uns des autres, menant à une confusion dans les indications des sources des composantes. Les résultats montrent que les isotopes de soufre et la teneur en zinc du minerai sont des indicateurs plus sensibles de la contamination par la croûte que les isotopes d'osmium, et concordent en général avec un modèle impliquant la fusion de sédiments pour le cas de Kambalda.

(Traduit par la Rédaction)

Mot-clés: bilan des masses, mélange, xénolithe, liquide silicaté externe, phase volatile externe, nickel (Ni), cuivre (Cu), éléments du groupe du platine (EGP), Kambalda, Australie. 


\section{INTRODUCTION}

Most magmatic $\mathrm{Ni}-\mathrm{Cu}-(\mathrm{PGE})$ sulfide deposits are interpreted to have formed from sulfide-undersaturated magmas (Keays 1982, 1995, Naldrett \& Barnes 1986) [note that the molten magmatic phases discussed in this paper include magmas (multiphase molten rocks or ores that existed beneath the Earth's surface), lavas (multiphase molten rocks or ores that existed on the Earth's surface), and melts (single molten phases that formed in either environment). For simplicity, we often use the term magma to refer to both magmas and lavas, but we reserve the term melt to refer to single phases generated during a partial or wholesale melting process]. Such deposits may form in lava channels or magma conduits by incorporation of crustal sulfur (e.g., Lesher 1989, Naldrett 1989). As a consequence, most deposits of this type exhibit variations in ore compositions that are attributed to mixing between silicate and sulfide magmas, and most exhibit physical, geochemical, or isotopic evidence of magma-crust interaction (Table 1). However, even deposits for which there is strong field and $\mathrm{S}$ isotopic evidence for thermomechanical erosion of country rocks do not appear to exhibit consistent geochemical or isotopic evidence of contamination.

For example, at Kambalda, Western Australia, there is a seemingly unequivocal combination of stratigraphic, field, geochemical, $\mathrm{S}, \mathrm{Nd}$, and $\mathrm{Pb}$ isotopic, and theoretical evidence for thermomechanical erosion of unconsolidated sulfide-bearing sediments to generate the sulfide ores (Groves et al. 1979, 1986, Huppert et al. 1984, Lesher et al. 1984, McNaughton et al. 1988, Frost \& Groves 1989, Lesher 1989, Dupré \& Arndt 1990, Lesher \& Arndt 1995, Williams et al. 1998, 1999a, b), but the Os isotopic compositions of some of the ores are slightly less radiogenic than expected (Foster et al. 1996). A variety of explanations can account for such a discrepancy, including: i) the inability of a single analysis of the consolidated, diagenetically modified, and regionally metamorphosed equivalent of the sediment to adequately represent the compositional diversity of the masses of unconsolidated sediments that could have been incorporated upstream from the site of ore deposition, ii) uncertainties in the calculated initial Os isotopic composition of the sedimentary unit owing to the long residence-time and large component of radiogenic Os, iii) uncertainties in estimates of the initial compositions of the magmas and the relative abundances of silicate magma and sulfide magma in the system (see discussion by Lesher \& Campbell 1993), and iv) the presence of additional phases such as crystalline solids (preserved as olivine and minor chromite), unmixed xenomelts [the terms xenomelt and xenovolatile are defined in this paper as silicate or sulfide melts and volatile phases derived from outside the original silicate magma by partial or complete anatexis of country rocks, a process that may also produce xenoliths or xenocrysts] (locally preserved as felsic ocellites [these rocks have been referred to previously as ocellar komatiites and ocellar units (see Frost \& Groves 1989); because they are composed primarily of felsic ocelli and often contain no significant komatiitic component, we refer to the rocks as felsic ocellites and the stratigraphic units as ocellar units] that locally occur adjacent to the lava channels: Fig. 1), and unincorporated restites (locally preserved as chloritic metasediments that flank the lava channels: Fig. 1), all of which may contribute and retain certain elemental and isotopic components.

In this paper, we have focused on the last point and have derived multicomponent elemental and isotopic mass-balance equations to show how the inclusion of additional phases can greatly influence mass-balance calculations. Magmatic sulfide ores form through a large number of different physical processes, including partial or fractional or equilibrium crystallization and segregation of magma and sulfides, magma replenishment and flow-through, zone refining, and batch equilibration (e.g., Campbell \& Naldrett 1979, Naldrett 1989, Barnes \& Picard 1993, Brügmann et al. 1993, Lesher \& Campbell 1993, Lesher \& Stone 1996, Barnes 1999). Although fractional crystallization and segregation processes are more important in disseminated sulfide deposits, batch and zone-refining processes are more important in massive sulfide deposits. The emphasis here will be on batch equilibration, which represents a well-constrained end-member in ore-forming magmatic systems.

\section{Two-Component Systems}

\section{Metal partitioning}

The partitioning of an element $\mathrm{i}$ between a silicate magma and a sulfide magma during batch equilibration has been discussed by Campbell \& Naldrett (1979), Naldrett (1981), and Campbell \& Barnes (1984). If all of the sulfide is derived internally, for example by cooling, oxidation, increase in the proportion of felsic components, or fractionation of the magma, the relationship between the final concentration of element $i$ in the sulfide magma $Y_{i}{ }^{f}$ and the initial concentration of element $\mathrm{i}$ in the silicate magma $\mathrm{X}_{\mathrm{i}}^{0}$ is (Campbell \& Naldrett 1979):

$$
\mathrm{Y}_{\mathrm{i}}^{\mathrm{f}}=\frac{\mathrm{X}_{\mathrm{i}}^{0} \mathrm{D}_{\mathrm{i}}^{\mathrm{Sul} / \mathrm{Sil}}(\mathrm{R}+1)}{\mathrm{R}+\mathrm{D}_{\mathrm{i}}^{\text {Sul } / \mathrm{Sil}}}
$$

where $\mathrm{D}_{i}^{\text {Sul/Sil }}$ is the sulfide-silicate partition coefficient, and $\mathrm{R}$ is the silicate:sulfide mass-ratio. If all of the sulfide is derived externally, for example by desulfidation or assimilation of country rocks, the relationship is (Naldrett 1981): 


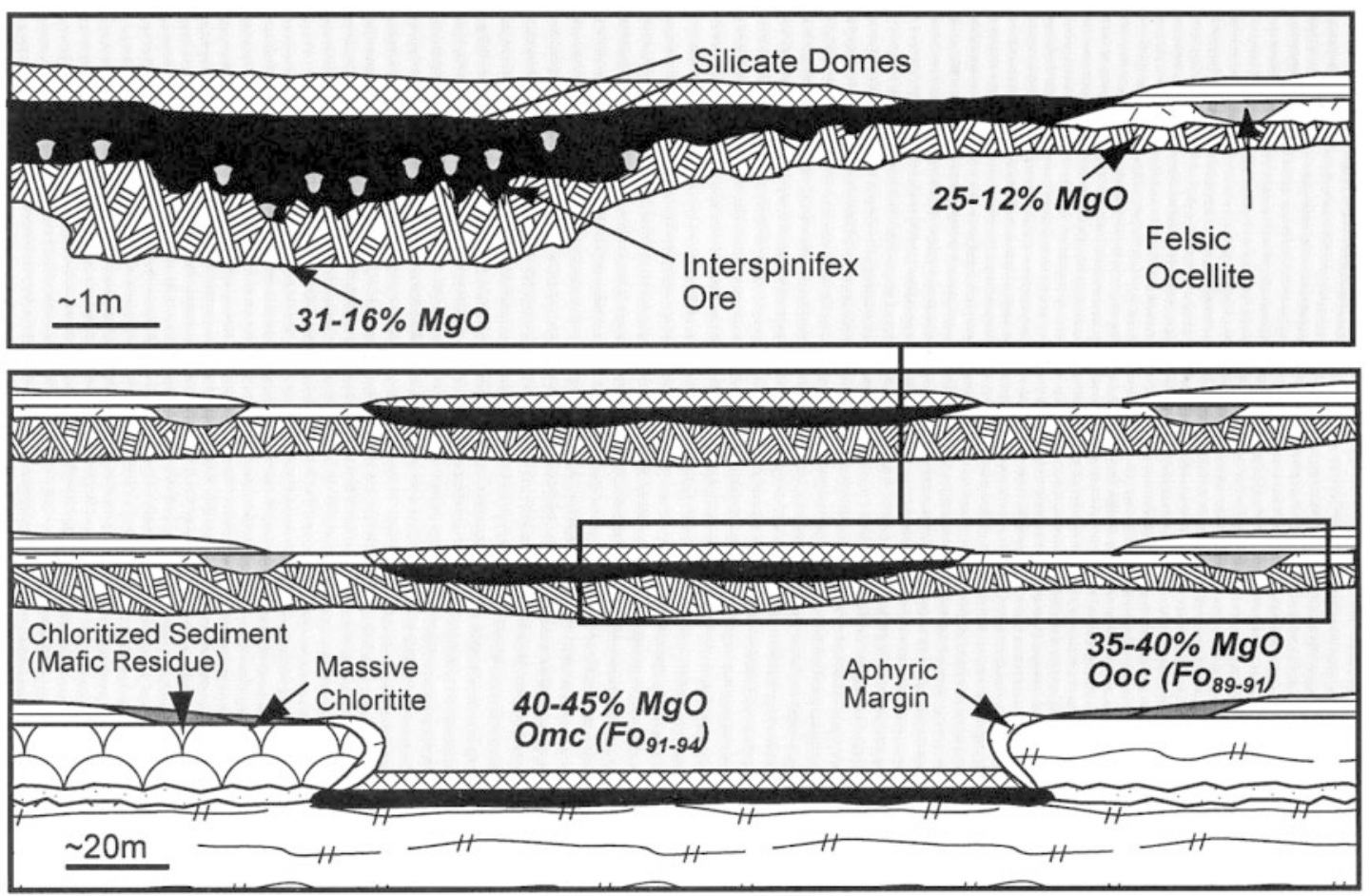

Massive Sulfides

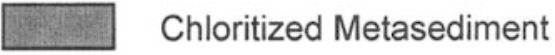

Sulfidic Metasediment

Pillow Metabasalt

Pillow Breccia/Hyaloclastite

Massive Metabasalt
"Silicate Dome"

Felsic Ocellite

Random-Spinifex Metakomatiite

Platy-Spinifex Metakomatiite

Cumulate Metakomatiite

Net-Textured and

Disseminated Sulfides

FIG. 1. Schematic section through a Kambalda ore environment after removal of superimposed deformation (adapted from Gresham \& Loftus-Hills 1981, Lesher et al. 1981, 1984, Lesher \& Groves 1984, Groves et al. 1986, Frost \& Groves 1989, Lesher 1989). Scales are approximate (see discussion in Appendix).

$$
Y_{i}^{f}=\frac{X_{i}^{0} D_{i}^{S u l / S i l} R}{R+D_{i}^{S u l / S i l}}
$$

These equations have been widely used in the literature to model variations in the compositions of sulfide ores in systems with variable R (e.g., Naldrett et al. 1979, Barnes \& Picard 1993, Lesher \& Campbell 1993, Lambert et al. 1998a, Maier et al. 1998, Ripley et al. 1999, Barnes 1999). However, as we shall see, Equation 2 is only applicable in special cases, and not all ore-forming systems meet the restrictions. In order to gain further insight into the restrictions (and limitations), we must return to first principles.

Mass conservation requires that the masses of element $\mathrm{i}$ distributed between the final silicate magma and the final sulfide magma must be equal to the masses of element $\mathrm{i}$ distributed between the initial silicate magma and initial sulfide magma:

$$
A^{f} X_{i}^{f}+B^{f} Y_{i}^{f}=A^{0} X_{i}^{0}+B^{0} Y_{i}^{0}
$$


TABLE 1. SUIMMARY OF EVIDENCE FOR WIIOLESALE, PARTIAL, OR INCONGRUFINT MFI.TTNG AT SLLLECI'ED MAGMA TIC NG-Cu-(PGE) SILFIOE DEPOSTTS

\begin{tabular}{|c|c|c|}
\hline Leposit & Physical Evidence & Georhemical Evidence \\
\hline \multicolumn{3}{|c|}{ Komatiitic } \\
\hline Dultront & None (disseminated intergtitial sulfides) & None (uncontaminated?) \\
\hline Fortestatia & $\begin{array}{l}\text { Stratigraphic losation; themal crosional } \\
\text { embayments; rare xenoliths }\end{array}$ & Local $L R E S-L I L E$ chrichunent \\
\hline Kamibalda & 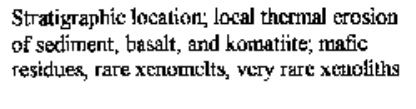 & 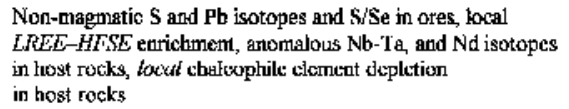 \\
\hline Latgratuir & $\begin{array}{l}\text { Stratigraphic location; local themal erosion; } \\
\text { themul crosion embayment? }\end{array}$ & Non-magnatic S isotopes and S/Se values \\
\hline Mt Keith-Betherno & None (diaseminated intersritial sulfides) & None (uncontarninated?) \\
\hline Pęrseverance & Themal ctosional etwbayment? & 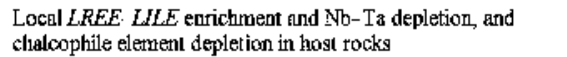 \\
\hline Thompsen & $\begin{array}{l}\text { Stratigraphic location; jocal thermal erosion; } \\
\text { skerts }\end{array}$ & 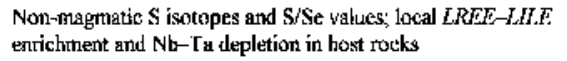 \\
\hline 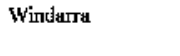 & $\begin{array}{l}\text { Stratigraphic location thermal erosional } \\
\text { embaytments }\end{array}$ & Non-magnatic S isotopes and S/Se wahes \\
\hline \multicolumn{3}{|c|}{ Komatitic Btasaltic - Pieritic - Fer'ouptóntic } \\
\hline Namew Lake & Local orbicular textures & $\begin{array}{l}\text { Anomalous Cu-Zn-Pb abundances and } \mathrm{Pb} \text { isotopes in ores; } \\
L R E E-L I L E \text { enrichment in host rocks }\end{array}$ \\
\hline Pechentera & $\begin{array}{l}\text { Stratipraphic location, contact-tucta- } \\
\text { morphosed wall tooks, xenoliths. }\end{array}$ & Anomalous $S$ and $O$ s isotepes in ores \\
\hline Raglas & $\begin{array}{l}\text { Stratigraphic luctation, thesmal ecrsional } \\
\text { enbatyments, contact-metanorphosed } \\
\text { footpall rocks }\end{array}$ & 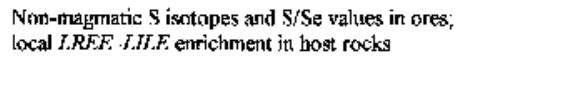 \\
\hline \multicolumn{3}{|c|}{ Easaltic } \\
\hline Duluth & $\begin{array}{l}\text { Stratigaphic location, contact meta- } \\
\text { morphosed wall rocks, xenoliths }\end{array}$ & 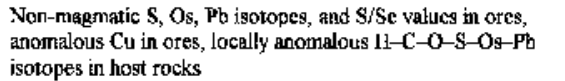 \\
\hline Naril'sk & Xonolitbs, taxitic gabbro, exten sive skams & 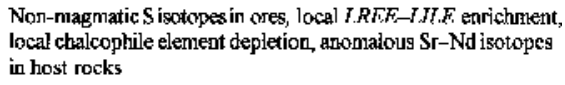 \\
\hline Voisey's Bay & Abundant xenoliths & $\begin{array}{l}\text { Non-magnatic S and Os isotopes in ores, non-nagmatic } \\
\text { O isotopes in host racks; thinar nen-magnatic Nd-Sn-Pb } \\
\text { isotopes in host rocks; local depletion in chalcophile elements } \\
\text { in bost rocks }\end{array}$ \\
\hline
\end{tabular}

\section{Crust-Domingted}

Suntury

Extensive breccia zortes, abundaral xelioliths.

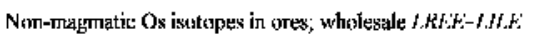
enrichroent, and crustal $S_{r}$ and Nd isotepes in host rocks

Keferences: Dututh: Mainwaring \& Najdret (1977), Ripley (1981, 1986a, 1950), Ripley \& Al-Jassar (1987), Ripley \& Alawi (198:),

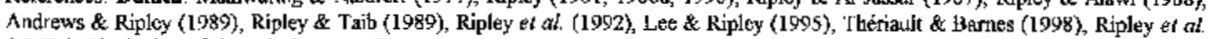

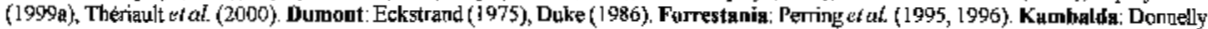

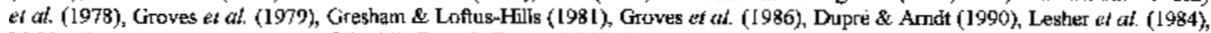
MeNanghton et al (1988), Evans at al (1989), Ftost \& Growes (1989), Lesher (1989), Cowden k Robents (1995), Lesher \& Andt (1995), Stone \& Wasterman (1998), Williaths at al (1998, 1999), Legher er al (1999h, 2001). Langmutr: Green \& Naldrett (1981), Mi

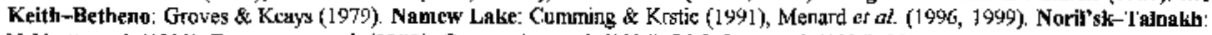

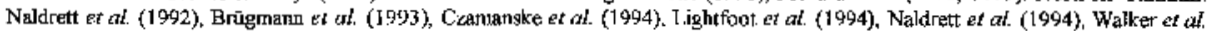
(1994a, b) Andt ef al. (1998), Naldrett \& Light Foot (1999). Pecheng*: Gritento \& Smol'kin (199 I), Melezhik al al (1994). Walket en

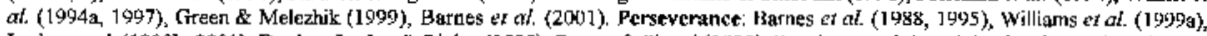

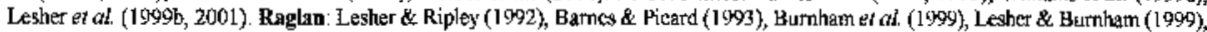

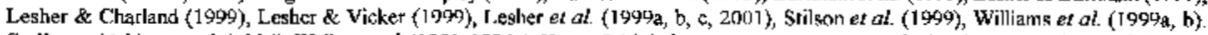

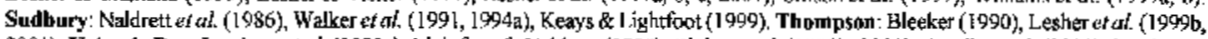

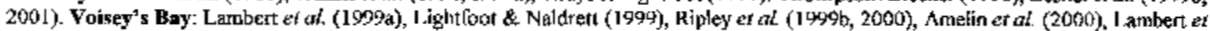
al' (2000), Li \& Naldrett (2000), Li et ail. (2000). Wisdarra: Gropes et al. (1979), T,esher (1989), 
where $\mathrm{A}$ is the mass fraction of silicate magma, and B is the mass fraction of sulfide magma.

$$
\text { Substituting } \mathrm{Y}_{\mathrm{i}}^{\mathrm{f}}=\mathrm{D}_{\mathrm{i}}^{\mathrm{Sul} / \mathrm{Sil}} \mathrm{X}_{\mathrm{i}}^{\mathrm{f}} \text {, and } \mathrm{X}_{\mathrm{i}}^{\mathrm{f}}=\frac{\mathrm{Y}_{\mathrm{i}}^{\mathrm{f}}}{\mathrm{D}_{\mathrm{i}}^{\text {Sul/Sil }}} \text {, }
$$

and rearranging, one obtains:

$$
\begin{aligned}
& X_{i}^{f}=\frac{A^{0} X_{i}^{0}+B^{0} Y_{i}^{0}}{A^{f}+B^{f} D_{i}^{\text {Sul/Sil }}} \\
& Y_{i}^{f}=\frac{\left(A^{0} X_{i}^{0}+B^{0} Y_{i}^{0}\right) D_{i}^{\text {Sul/Sil }}}{A^{f}+B^{f} D_{i}^{\text {Sul/Sil }}}
\end{aligned}
$$

Substituting $\mathrm{R}=\mathrm{A} / \mathrm{B}$, one obtains (Lesher \& Burnham 1999):

$$
Y_{i}^{f}=\frac{\left(X_{i}^{0} R+Y_{i}^{0}\right) D_{i}^{S u l / S i l}}{R+D_{i}^{\text {Sul/Sil }}}
$$

If the assimilant contains no sulfide, then $\mathrm{B}^{0}=0$ and $\mathrm{A}^{0}$ $=1$, and $\mathrm{R}=\mathrm{A}^{\mathrm{f}} / \mathrm{B}^{\mathrm{f}}$, so that Equation 5 reduces to Equation 1. If the assimilant contains a sulfide component devoid of element $i$ (and the magma is close to sulfide saturation, see Discussion), then $Y_{i}^{0}=0$, and and the majority of the sulfide magma will originate from the assimilant, such that $R=A^{f} / B^{f}=A^{0} / B^{0}$. Under these conditions, Equation 5 reduces to Equation 2. However, if $\mathrm{Y}_{\mathrm{i}}^{0}>0$, Equation 5 must be used. These three situations, implications, and the appropriate mass-balance equations are summarized in Table 2; some general examples were presented by Lesher \& Burnham (1999). As pointed out by Campbell \& Naldrett (1979) and as is evident also from inspection of the examples presented by Lesher \& Burnham (1999) and later in this paper, if $\mathrm{R}>10 \mathrm{D}$ and if $\mathrm{Y}_{\mathrm{i}}^{0}<<\mathrm{X}_{\mathrm{i}}^{0}$, the results from Equations 1 , 2 , and 5 are not significantly different. However, if $\mathrm{R}<$ 10D, which is commonly the case (e.g., Naldrett et al. 1979, 1995, Lesher \& Campbell 1993, Barnes \& Picard 1993, Menard et al. 1996, Ripley et al. 1999), or if $Y_{i}^{0}$ $>\mathrm{X}_{\mathrm{i}}{ }^{0}$, which may be the case (e.g., Tyson \& Chang 1984, Lesher \& Campbell 1993, Lee \& Ripley 1995, Menard et al. 1996, Thériault \& Barnes 1998), the results may be quite different.

\section{Isotope mixing}

The geochemistry of the stable and radiogenic isotope systems that are relevant to magmatic ore genesis has been reviewed by Faure (1986), Ohmoto (1986), Heaman \& Ludden (1991) and Dickin (1995). Because mantle and crustal reservoirs are generally isotopically distinct and because the most commonly used radiogenic isotopes are considered too heavy to fractionate significantly during fractional crystallization, isotope data, in general, and radiogenic isotope data, in particular, are quite valuable in evaluating the effects of contamination by crust.

The equations that describe the mixing of two components having different abundances of an element and different isotopic ratios of that element have been reviewed by Faure (1986) and illustrated by Dickin (1995). The mass balance in a two-component system (e.g., a magma and a contaminant) is:

$$
R_{M_{i}}^{f}=\frac{\frac{R_{A_{i}}^{0} X_{A_{i}}^{0} f}{W_{A_{i}}^{0}}+\frac{R_{B_{i}}^{0} X_{B_{i}}^{0}(1-f)}{W_{B_{i}}^{0}}}{\frac{X_{A_{i}}^{0} f}{W_{A_{i}}^{0}}+\frac{X_{B_{i}}^{0}(1-f)}{W_{B_{i}}^{0}}}
$$

where $R_{M_{i}}^{f}$ is the final isotopic ratio (or normalized isotopic ratio) of element $i$ in the mixture, $R_{\mathrm{A}_{i}}^{0}$ and $\mathrm{R}_{\mathrm{B}_{\mathrm{i}}}^{0}$ are the initial (age-corrected) isotopic ratios of components $\mathrm{A}$ and $\mathrm{B}, \mathrm{X}_{\mathrm{A}_{\mathrm{i}}}^{0}$ and $\mathrm{X}_{\mathrm{B}_{\mathrm{i}}}^{0}$ are the initial abundances of element $\mathrm{i}$, including the age-corrected radiogenic component, in components $\mathrm{A}$ and $\mathrm{B}, \mathrm{W}_{\mathrm{A}_{\mathrm{i}}}^{0}$ and $\mathrm{W}_{\mathrm{B}_{\mathrm{i}}}^{\mathrm{O}}$ are the atomic weights of element $i$ in components $A$ and $\mathrm{B}$, and $f$ and $1-f$ are the mass fractions of components $\mathrm{A}$ and $\mathrm{B}$.

In most cases, the differences in atomic mass are very small (see discussion by Lesher \& Burnham 1999); therefore, if we assume that the atomic weight of $i$ is the same in A and B, Equation 6 reduces to (Faure 1986):

$$
R_{M_{i}}^{f}=\frac{R_{A_{i}}^{0} X_{A_{i}}^{0} f+R_{B_{i}}^{0} X_{B_{i}}^{0}(1-f)}{X_{A_{i}}^{0} f+X_{B_{i}}^{0}(1-f)}
$$

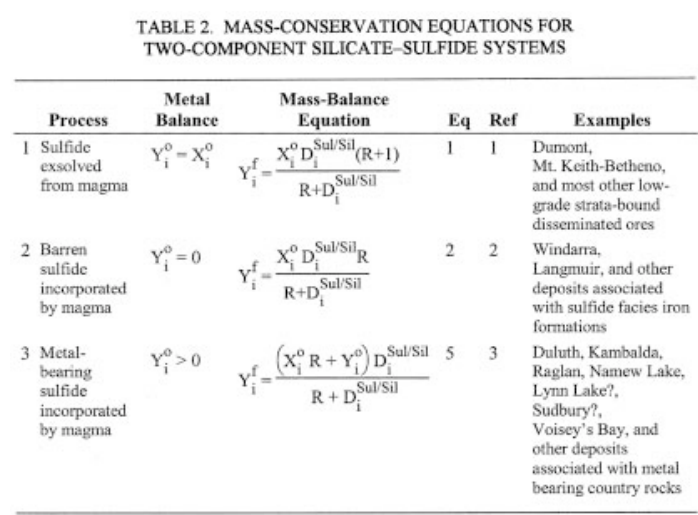

Eq: equations numbered in text. Ref. references to equations. 1: Campbell \& Naldrett (1979), 2: Naldrett (1981), 3: Lesher \& Burnham (1999, this paper). References to examples in Table 
As discussed by Lesher \& Stone (1996; see also Lambert et al. 1998a, Ripley et al. 1999), in order to model the effects of isotopic mixing in such a system, $f$ must be modified to account for the relative proportion of magma that has equilibrated with the sulfides. Because $f+(1-f)=1$ and $R=f /(1-f), f=R /(1+R)$ and $1-f$ $=1 /(1+R)$, Equation 6 becomes (Lesher $\&$ Stone 1996):

$$
\mathrm{R}_{\mathrm{M}_{\mathrm{i}}}^{\mathrm{f}}=\frac{\mathrm{R}_{\mathrm{A}_{\mathrm{i}}}^{0} \mathrm{X}_{\mathrm{A}_{\mathrm{i}}}^{0}\left(\frac{\mathrm{R}}{1+\mathrm{R}}\right)+\mathrm{R}_{\mathrm{B}_{\mathrm{i}}}^{0} \mathrm{X}_{\mathrm{B}_{\mathrm{i}}}^{0}\left(\frac{1}{1+\mathrm{R}}\right)}{\mathrm{X}_{\mathrm{A}_{\mathrm{i}}}^{0}\left(\frac{\mathrm{R}}{1+\mathrm{R}}\right)+\mathrm{X}_{\mathrm{B}_{\mathrm{i}}}^{0}\left(\frac{1}{1+\mathrm{R}}\right)}
$$

Note that Equation 8 is equivalent to the expression used by Lambert et al. (1999), but it is not equivalent to the expression used by Foster et al. (1996), which is not balanced for mass. If atomic weight terms are included, Equation 8 becomes:

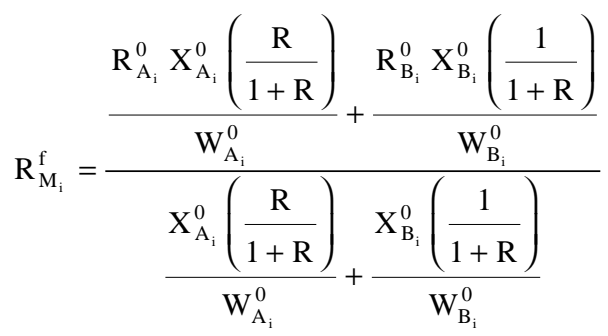

The results of mixing calculations using equations of the form of Equation 8 have been discussed by Lesher \& Stone (1996), Lambert et al. (1999), Lesher \& Burnham (1999), and Ripley et al. (1999). The most important observations are that signatures due to crustal contamination are easily erased in systems that formed at high $\mathrm{R}$, and that this occurs at different values of $\mathrm{R}$ for different isotopic systems.

\section{Multicomponent Systems}

In many cases, the process of incorporation of external sulfide involves disaggregation, partial melting, or devolatilization of wallrocks, which may result in the production of a sulfide xenomelt, a silicate xenomelt, a volatile component, or a restite (see references in Table 1). Unless the magma is superheated, interaction with country rocks must also induce crystallization. Thus in many cases, natural systems cannot be modeled in terms of two components.

\section{Metal partitioning}

Addition of terms for initial and final xenomelt and volatile phases $\left(Z_{i}^{0}\right.$ and $\left.Z_{i}^{f}\right)$, initial and final restites $\left(Q_{i}{ }^{0}\right.$ and $\left.\mathrm{Q}_{\mathrm{i}}^{\mathrm{f}}\right)$, and initial and final crystalline solids $\left(\mathrm{S}_{\mathrm{i}}{ }^{0}\right.$ and $\mathrm{S}_{\mathrm{i}}^{\mathrm{f}}$ ), plus their corresponding mass-fraction terms $\mathrm{C}, \mathrm{E}$, and $\mathrm{F}$ in Equation 3, yields:

$$
\begin{aligned}
& A^{f} X_{i}^{f}+B^{f} Y_{i}^{f}+C^{f} Z_{i}^{f}+E^{f} Q_{i}^{f}+F^{f} S_{i}^{f}= \\
& A^{0} X_{i}^{0}+B^{0} Y_{i}^{0}+C^{0} Z_{i}^{0}+E^{0} Q_{i}^{0}+F^{0} S_{i}^{0}
\end{aligned}
$$

If we define the corresponding partition-coefficients as $\mathrm{D}_{\mathrm{i}}^{\mathrm{Sul} / \mathrm{Sil}}, \mathrm{D}_{\mathrm{i}}^{\mathrm{Xen} / \mathrm{Sil}}, \mathrm{D}_{\mathrm{i}}^{\mathrm{Res} / \mathrm{Sil}}$, and $\mathrm{D}_{\mathrm{i}}^{\mathrm{Xt} / \mathrm{Sil}}$, then $\mathrm{Y}_{\mathrm{i}}^{\mathrm{f}}=\mathrm{D}_{\mathrm{i}}{ }_{\mathrm{i}}^{\mathrm{Sul} / \mathrm{Sil}}$ $\mathrm{X}_{\mathrm{i}}^{\mathrm{f}}, \mathrm{Z}_{\mathrm{i}}^{\mathrm{f}}=\mathrm{D}_{\mathrm{i}}{ }^{\mathrm{Xen} / \mathrm{Sil}} \mathrm{X}_{\mathrm{i}}^{\mathrm{f}}, \mathrm{Q}_{\mathrm{i}}^{\mathrm{f}}=\mathrm{D}_{\mathrm{i}}{ }^{\mathrm{Re} / \mathrm{Sil}} \mathrm{X}_{\mathrm{i}}^{\mathrm{f}}$, and $\mathrm{S}_{\mathrm{i}}^{\mathrm{f}}=\mathrm{D}_{\mathrm{i}}^{\mathrm{Xt} / \mathrm{Sil}}$ $\mathrm{X}_{\mathrm{i}}^{\mathrm{f}}$. Substitution into Equation 10 yields the following equations for the abundances of element $\mathrm{i}$ in the final phases (Lesher \& Burnham 1999):

$$
\begin{aligned}
& \mathrm{X}_{\mathrm{i}}^{\mathrm{f}}=\frac{\mathrm{A}^{0} \mathrm{X}_{\mathrm{i}}^{0}+\mathrm{B}^{0} \mathrm{Y}_{\mathrm{i}}^{0}+\mathrm{C}^{0} \mathrm{Z}_{\mathrm{i}}^{0}+\mathrm{E}^{0} \mathrm{Q}_{\mathrm{i}}^{0}+\mathrm{FS}_{\mathrm{i}}^{0}}{\mathrm{~A}^{\mathrm{f}}+\mathrm{B}^{\mathrm{f}} \mathrm{D}_{\mathrm{i}}^{\mathrm{Sul} / \mathrm{Sil}}+\mathrm{C}^{\mathrm{f}} \mathrm{D}_{\mathrm{i}}^{\mathrm{Xen} / \mathrm{Sil}}+\mathrm{E}^{\mathrm{f}} \mathrm{D}_{\mathrm{i}}^{\text {Res } / \mathrm{Sil}}+\mathrm{F}^{\mathrm{f}} \mathrm{D}_{\mathrm{i}}^{\mathrm{Xt} / \mathrm{Sil}}} \\
& Z_{i}^{f}=\frac{\left(A^{0} X_{i}^{0}+B^{0} Y_{i}^{0}+C^{0} Z_{i}^{0}+E^{0} Q_{i}^{0}+F^{0} S_{i}^{0}\right) D_{i}^{X e n / S i l}}{A^{f}+B^{f} D_{i}^{\text {Sul/Sil }}+C^{f} D_{i}^{X e n / S i l}+E^{f} D_{i}^{\text {Res } / \text { Sil }}+F^{f} D_{i}^{X t / S i l}}
\end{aligned}
$$

$$
S_{i}^{f}=\frac{\left(A^{0} X_{i}^{0}+B^{0} Y_{i}^{0}+C^{0} Z_{i}^{0}+E^{0} Q_{i}^{0}+F^{0} S_{i}^{0}\right) D_{i}^{X t / / S i l}}{A^{f}+B^{f} D_{i}^{S u l / S i l}+C^{f} D_{i}^{X e n / S i l}+E^{f} D_{i}^{\text {Res } / S i l}+F^{f} D_{i}^{X t / / S i l}}
$$

Note that these equations are of the same form as Equation 4. Additional terms may be added to (or removed from) Equations $11-15$ as required. For example, the restite or crystalline solid may be separated into different components. Terms also may be combined. For example, the composition of a contaminated magma, $\mathrm{XZ}_{\mathrm{i}}^{\mathrm{f}}$, if one assumes that the silicate (or volatile component) of the contaminant is completely mixed into the magma, may be calculated by mixing the final silicate magma, xenomelt, and xenovolatile phases.

As discussed by Lesher \& Burnham (1999), this is a mass-balance equation between end-member components: 1) a silicate magma, 2) the silicate or volatile component of a contaminant, 3 ) the sulfide component of a contaminant, 4) the residual component of a contaminant, and 5) a crystalline solid. It may be applied to an initial system, for example using the composition of a parental magma, or it may be applied to a derivative system, for example using the composition of a derivative magma at the point of sulfide saturation if that is 
known (see discussion by Lesher \& Campbell 1993, Lambert et al. 1998a). The only provision is that the elemental abundances, partition coefficients, and mass proportions must be appropriate for the specified system. Parameterizing initial compositions is normally easier than parameterizing intermediate compositions, and it avoids potential violations of mass conservation when redistributing elements among derivative compositions (see Discussion).

If we define $R^{\prime}=A /(B+C+E+F)$, which is analogous to $\mathrm{R}=\mathrm{A} / \mathrm{B}$, we can calculate $\mathrm{X}_{\mathrm{i}}^{\mathrm{f}}, \mathrm{XZ}_{\mathrm{i}}^{\mathrm{f}}, \mathrm{Y}_{\mathrm{i}}^{\mathrm{f}}, \mathrm{Z}_{\mathrm{i}}^{\mathrm{f}}, \mathrm{Q}_{\mathrm{i}}^{\mathrm{f}}$, and $S_{i}{ }^{f}$ as a function of $R^{\prime}$ or invert the equations and solve for R'. The effects of changing the relative abundances of sulfide, xenomelt \pm xenovolatile phase, restite, and crystallized solid as a function of R', the effects of changing the abundances of metal in the external sulfur source as a function R', and the results for different metals were illustrated by Lesher \& Burnham (1999).

\section{Isotope mixing}

If we assume isotopic equilibrium among the various components in the same system described in Equations 11-15, the isotopic ratio of the mixture (and therefore of each of the components) at the time of equilibration is:

$$
\begin{aligned}
& \frac{\mathrm{A}^{0} \mathrm{R}_{\mathrm{X}_{\mathrm{i}}}^{0} \mathrm{X}_{\mathrm{i}}^{0}}{\mathrm{~W}_{\mathrm{A}}}+\frac{\mathrm{B}^{0} \mathrm{R}_{\mathrm{Y}_{\mathrm{i}}}^{0} \mathrm{Y}_{\mathrm{i}}^{0}}{\mathrm{~W}_{\mathrm{B}}}+\frac{\mathrm{C}^{0} \mathrm{R}_{\mathrm{Z}_{\mathrm{i}}}^{0} \mathrm{Z}_{\mathrm{i}}^{0}}{\mathrm{~W}_{\mathrm{C}}}
\end{aligned}
$$

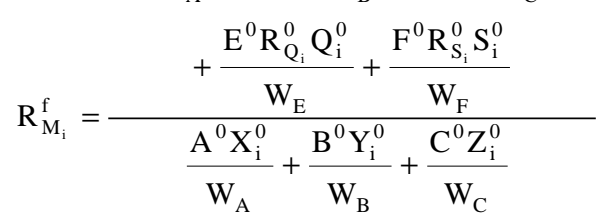

$$
\begin{aligned}
& +\frac{E^{0} Q_{i}^{0}}{W_{E}}+\frac{F^{0} S_{i}^{0}}{W_{F}}
\end{aligned}
$$

where $\mathrm{W}_{\mathrm{A}}, \mathrm{W}_{\mathrm{B}}, \mathrm{W}_{\mathrm{C}}, \mathrm{W}_{\mathrm{E}}$, and $\mathrm{W}_{\mathrm{F}}$ are the atomic weights, and $\mathrm{R}_{\mathrm{X}_{\mathrm{i}}}^{0}, \mathrm{R}_{\mathrm{Y}_{\mathrm{i}}}^{0}, \mathrm{R}_{\mathrm{Z}_{\mathrm{i}}}^{0}, \mathrm{R}_{\mathrm{Q}_{\mathrm{i}}}^{0}$, and $\mathrm{R}_{\mathrm{S}_{\mathrm{i}}}^{0}$ are the relevant age-corrected isotopic ratios (or normalized isotopic ratios) of the components defined above, e.g.,

$$
\left(\frac{{ }^{87} \mathrm{Sr}}{{ }^{86} \mathrm{Sr}}\right)^{0} \text { or } \varepsilon_{\mathrm{Sr}}{ }^{0},\left(\frac{{ }^{143} \mathrm{Nd}}{{ }^{144} \mathrm{Nd}}\right)^{0} \text { or } \varepsilon_{\mathrm{Nd}}{ }^{\mathrm{o}},\left(\frac{{ }^{187} \mathrm{Os}}{{ }^{188} \mathrm{Os}}\right)^{0} \text { or }
$$

$\gamma_{\mathrm{Os}}{ }^{0}, \delta^{34} \mathrm{~S}, \delta^{18} \mathrm{O}, \delta^{13} \mathrm{C}$, or $\delta \mathrm{D}$. Note that this equation is of the same form as Equation 6, and that the mass fractions $\mathrm{A}, \mathrm{B}, \mathrm{C}, \mathrm{E}$, and $\mathrm{F}$ replace $f$ and $1-f$.

If we make the same assumption as we did above, that $\mathrm{W}_{\mathrm{A}} \approx \mathrm{W}_{\mathrm{B}} \approx \mathrm{W}_{\mathrm{C}} \approx \mathrm{W}_{\mathrm{E}} \approx \mathrm{W}_{\mathrm{F}}$, Equation 16 may be simplified as follows (Lesher \& Burnham 1999):

$$
\begin{aligned}
& \mathrm{A}^{0} \mathrm{R}_{\mathrm{X}_{\mathrm{i}}}^{0} \mathrm{X}_{\mathrm{i}}^{0}+\mathrm{B}^{0} \mathrm{R}_{\mathrm{Y}_{\mathrm{i}}}^{0} \mathrm{Y}_{\mathrm{i}}^{0}+\mathrm{C}^{0} \mathrm{R}_{\mathrm{Z}_{\mathrm{i}}}^{0} \mathrm{Z}_{\mathrm{i}}^{0}
\end{aligned}
$$

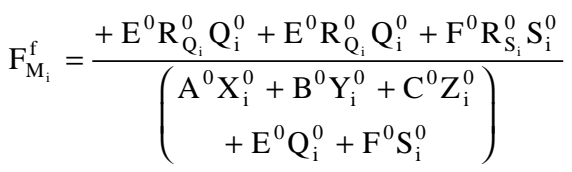

It is evident from inspection of Equations 16 or 17 that an important consequence of adding immiscible liquid, residual, or solid components to this system is that it changes the mass balance and may reduce the apparent degree of contamination at a given mass fraction of silicate magma through dilution, as illustrated by Lesher \& Burnham (1999).

\section{ERRORS}

When performing calculations like those described above, it is important to appreciate that there are considerable uncertainties in sampling and analytical results that are propagated thorough the calculations. For example, we are required to assume that the components of the systems being modeled have not changed from the time they were emplaced to the time they were analyzed, and that the elemental and isotopic systems have remained closed. In fact, there is considerable evidence in almost all magmatic ore deposits for interaction among ores, host rocks, and country rocks during diagenesis, seafloor alteration, contact metamorphism, or regional metamorphism, which may have occurred subsequent to ore genesis, even at relatively low metamorphic grades (e.g., Luck \& Allègre 1984, Luck \& Arndt 1985, McNaughton et al. 1988, Ripley et al. 1992, Shirey \& Barnes 1994, Walker et al. 1994a, 1997, Lahaye et al. 1995, Shirey \& Walker 1995, Foster et al. 1996, Lahaye \& Arndt 1996, Lambert et al. 1998b, 1999b). This interaction means, for example, that ores enclosed in sequences dominated by country rocks with chondritic isotopic characteristics (e.g., komatiites at Kambalda) may have inherited some of those characteristics, and that ores enclosed in sequences dominated by country rocks with non-chondritic isotopic characteristics (e.g., marls and evaporites at Noril'sk; metapelites, marbles, and iron-formations at Thompson; metapelites at Raglan and Pechenga), may have inherited some of those characteristics. The degrees of alteration of the ores and host rocks by fluids derived in the crust will be governed by mass-conservation constraints similar to those discussed in this paper, where the water:rock ratio (see discussion by Ohmoto 1986, Taylor 1997) is analogous to R or R'. For example, Lambert et al. (1998b) noted that Ni-Cu-(PGE) ores near major Au-rich shear zones are enriched in radiogenic Os, whereas ores well away from the shear zones have near-chondritic Os but radiogenic $\mathrm{Pb}$, which is consistent with the lower abundances of $\mathrm{Pb}$ in the ores being 
more susceptible to modification compared to Os. In any case, comprehensive studies involving large numbers of samples (e.g., Walker et al. 1997, Ripley et al. 1999) indicate that there are very large variations in the degree of alteration and that large datasets are required to properly evaluate the igneous processes.

There are also errors in geochemical and isotopic analyses. Although modern mass-spectrometric techniques can produce very precise data, the errors are magnified when the measured isotopic ratios are agecorrected and normalized (e.g., Sambridge \& Lambert 1997). This is especially true for samples containing low abundances of the isotopes, containing highly radiogenic components, or having long residence-times. For example, the 2700 Ma komatiite and metasedimentary material analyzed by Foster et al. (1996) had $\leq 4 \%$ errors in measured ${ }^{187} \mathrm{Re} /{ }^{188} \mathrm{Os}$ ratios and $\leq 0.7 \%$ errors in measured ${ }^{187} \mathrm{Os} /{ }^{188} \mathrm{Os}$ ratios (which include error magnifications in analysis and spike calibration), but the age corrections yielded a calculated initial ${ }^{187} \mathrm{Os} /{ }^{188} \mathrm{Os}$ ratio of $0.10963 \pm 0.0056$ and a calculated $\gamma_{\mathrm{Os}}$ value of $0.5 \pm 5$ (i.e., $\pm 1000 \%$ ) for the komatiite and a calculated initial ${ }^{187} \mathrm{Os} /{ }^{188} \mathrm{Os}$ ratio of $0.10963 \pm 0.0056$ and a calculated $\gamma_{O s}$ value of $912 \pm 210$ units (i.e., $\pm 23 \%$ ) for the metasediment. The propagated errors in the mixing calculations are therefore much greater than the -5 to +21 range of $\gamma_{O s}$ values measured in the ores (Foster $e t$ al. 1996) and must be taken into account when interpreting the results.

\section{ApPlicAtions}

Lesher \& Burnham (1999) presented a series of examples showing the relative influence of each of the parameters on final magma, sulfide, xenomelt, residue, and crystallized solid compositions. In this paper, we present specific models for metal and isotopic abundances at Kambalda, Western Australia.

\section{Metal variations at Kambalda}

Kambalda is the type example of komatiite-associated $\mathrm{Ni}-\mathrm{Cu}-(\mathrm{PGE})$ sulfide ore deposits (Lesher 1989). The ore compositions are relatively constant within individual shoots, but vary considerably between shoots (Gresham \& Loftus-Hills 1981, Ross \& Keays 1979, Keays et al. 1981, Cowden et al. 1986, Cowden \& Woolrich 1987). These variations do not appear to be attributable to metamorphic alteration or to supergene enrichment; we believe that they represent original magmatic variations. Lesher \& Campbell (1993) modeled the compositional variations by simultaneously solving Equation 2 for each component in the system and achieved a good fit to the observed compositions of the ore; they did not allow for the influence of silicate xenomelts, residues, or crystalline solids, however.

The parameters used in our models are given in Table 3. The composition of the parental magma $\left(\mathrm{X}^{0}\right)$ has been estimated from the average of 75 least-altered random spinifex-textured komatiites, back-fractionated to be in equilibrium with the most magnesian olivine analyzed (Fo94) (Lesher \& Arndt 1995). Two derivative magmas were also tested, one derived by $30.5 \%$ fractional crystallization $(24 \% \mathrm{MgO}$, representing an intermediate fractionated liquid) and one derived by $50.5 \%$ fractional crystallization $(12 \% \mathrm{MgO}$, representing the least-magnesian derivative liquid in the sheet-flow facies of the host units).

The composition of the bulk contaminant has been estimated from the composition of an average siliceous, sulfidic metasediment (Bavinton \& Keays 1978, Bavinton \& Taylor 1980, Bavinton 1981). The composition of the initial sulfide melt $\left(\mathrm{Y}^{0}\right)$ has been estimated from that of the average metasediment, assuming that all metals are hosted by the sulfide phase. The precious metals were probably mobile during metamorphism (Bavinton \& Keays 1978), but this composition is adequate for illustrative purposes. The composition of the initial xenomelt $\left(\mathrm{Z}^{0}\right)$ has been estimated from the average felsic ocellite at Kambalda (Frost \& Groves 1989; C.M. Lesher \& R.R. Keays, unpubl. data). The composition of the initial restite $\left(Q^{0}\right)$ has been estimated from the average mafic metasedimentary unit at Kambalda (Bavinton \& Keays 1978, Bavinton \& Taylor 1980, Bavinton 1981). Bavinton (1979, 1981) interpreted these rocks as sediments with more mafic and ultramafic detrital components and less felsic components than the more abundant siliceous metasedimentary rocks, but 1) their ratios of refractory trace elements are virtually identical to those in the siliceous metasedimentary material that covers the contact away from the ore zones, 2) they are thickest in the transition zones between the channel-flow and sheet-flow facies at Kambalda, 3) they are associated with thin zones of severely altered cherty metasedimentary material with thick fringing biotite halos and with isolated pods of siliceous sediments that cannot be correlated laterally between drill cores, 4) they grade laterally into massive chloritites toward the lava channels, and 5) they grade laterally into siliceous metasedimentary units away from the lava channels (Bavinton 1979). On this basis, they were interpreted by Lesher $(1983,1989)$ as devolatilized sediments.

The compositions of the initial crystalline solid $\left(\mathrm{S}^{0}\right)$ can be estimated to be olivine in equilibrium with the parental komatiitic magma or the integrated bulk-composition of the cumulate phases (primarily olivine) for the derivative magmas.

The sulfide magma/silicate magma partition coefficients $\left(\mathrm{D}_{\mathrm{i}}^{\mathrm{Sul} / \mathrm{Sil}}\right)$ are those calculated by Lesher \& Campbell (1993; cf. compilations by Lesher \& Stone 1996, Mathez 1999), except for $\mathrm{D}_{\mathrm{Zn}}$ Sul/Sil, which is estimated to be $\sim 2.5$ (see below). The silicate xenomelt/silicate magma $\left(\mathrm{D}_{\mathrm{i}}^{\mathrm{Xen} / \mathrm{Sil}}\right)$, restite/silicate magma $\left(\mathrm{D}_{\mathrm{i}}^{\mathrm{Res} / \mathrm{Sil}}\right)$, and equilibrium solid/silicate magma $\left(\mathrm{D}_{\mathrm{i}}^{\mathrm{Sol} / \mathrm{Sil}}\right)$ partition coefficients are calculated from the compositions in Table 3 . $\mathrm{D}_{\mathrm{Os}}$ is assumed to be equal to $\mathrm{D}_{\mathrm{Ir}}$ for all phases. 
TABLE 3. MODEL PARAMETERS FOR KAMBALDA

\begin{tabular}{|c|c|c|c|c|c|c|c|c|c|c|c|}
\hline & $\begin{array}{c}1 \\
\text { Patcontal } \\
\text { Magna } \\
\left(X^{4}\right)\end{array}$ & $\begin{array}{c}2 \\
\text { Equilibrium } \\
\text { Olinjile } \\
\text { (s) }^{0}\end{array}$ & $\begin{array}{c}3 \\
\text { Derivative } \\
\text { Magna } \\
\text { (x) }\end{array}$ & $\begin{array}{c}4 \\
\text { Bullk } \\
\text { Solid } \\
\left(S^{i}\right)\end{array}$ & $\begin{array}{c}5 \\
\text { Dorivatiwe } \\
\text { hlagmat } \\
\left(\mathrm{X}^{2}\right)\end{array}$ & $\begin{array}{c}6 \\
\text { fulk } \\
\text { solid } \\
\left(\mathrm{s}^{2}\right)\end{array}$ & $\begin{array}{c}7 \\
\text { Bulk } \\
\text { Cofilatinjutat }\end{array}$ & $\begin{array}{c}8 \\
\text { Sulficle } \\
\text { Xenomelt } \\
\left(Y^{\prime}\right)\end{array}$ & $\begin{array}{c}9 \\
\text { Silicalc } \\
\text { Xenomelt } \\
\left(Z^{0}\right)\end{array}$ & $\begin{array}{c}\text { J estite } \\
\left(0^{\circ}\right)\end{array}$ & Otes \\
\hline Co (ppm) & 115 & 100 & 114 & 116 & 89 & 140 & 119 & 703 & 10 & 174 & $0.2-6.3 \%$ \\
\hline Ni (PJm) & 1700 & 2470 & 1210 & 2950 & $29 \mathrm{~g}$ & $306 \mathrm{x}$ & 203 & 1254 & 47 & 327 & $8-22 \%$ \\
\hline Cu (pom) & 45 & nill & 62 & nil & 90 & nil & 497 & 2676 & 9 & 465 & $0.6-1.3 \%$ \\
\hline Zn (gpmin) & 65 & nit & 89 & nil & 130 & nil & 1595 & 8467 & 539 & 1394 & $0.02-0.04 \%$ \\
\hline $\mathrm{l} d(p p b)$ & 6.0 & trif & 8.2 & nil & 12 & nil & 5.1 & 55 & 2.0 & 12 & $1510-7460$ \\
\hline $\operatorname{Ir}(\mathrm{ppb})$ & 2.1 & 7.0 & 0.96 & 3. 1 & 0.36 & 3.8 & 0.27 & 1.6 & 0.11 & 0.61 & $160-350$ \\
\hline Os (ppb) & 2,0 & 6.7 & 0.91 & 4.8 & 0.35 & 3.6 & 0.27 & 1.6 & 0.11 & 0.61 & $270-980$ \\
\hline$y(2700)$ & 0 & $n$ & 0 & 0 & 0 & 0 & +900 & +900 & +900 & +900 & $-5 \mathrm{to}+21$ \\
\hline$S(t / 0)$ & 0.05 & niil & 0.68 & nil & 1.0 & nil & 5.0 & 38 & 0.23 & 9.4 & $35-39 \%$ \\
\hline$\delta^{3-1} 5$ & 0 & -- & 6 & - & 0 & -- & +4 & +4 & +4 & +4 & 10.8 to 13.8 \\
\hline $\mathrm{SiSe}$ & 3,333 & -- & 3,333 & -- & 3,333 & -- & 20000 & 20,000 & 20,010 & $20,0[0)$ & $7,600-11,300$ \\
\hline$\left[\mathbf{J}_{\mathrm{C}_{\mathrm{t1}}}\right.$ & & $0.87^{4 * *}$ & & $1 \_[]^{* * *}$ & & $1.6^{m+x}$ & & $30^{k}$ & {$\left[1.14^{*-*}\right.$} & $2.4^{+1 *}$ & \\
\hline $\mathrm{D}_{\mathrm{Ni}}$ & & 1.5 & & 2.5 & & 10 & & $100-200$ & 0.14 & 10 & \\
\hline 1$)_{C .41}$ & & nil & & nil & & เii] & & 600 & 0.15 & 7.9 & \\
\hline$D_{Z l}$ & & til & & mil & & nil & & $(25)$ & 3.1 & 8.0 & \\
\hline $\mathrm{C}_{\mathrm{Pd}}$ & & nil & & nil & & mil & & 30.000 & 0.24 & 1.5 & \\
\hline $\mathrm{D}_{\mathrm{Ir}^{-}-} \mathrm{D}_{\mathrm{O}}$ & & 4,3 & & 5.3 & & 10 & & 30,000 & 0.20 & 1.3 & \\
\hline
\end{tabular}

Columns; 1 : Parental komatiitic magna (adapted fron Lesher \& Campbell 1993, Lesher \& Amdt 1995). 2 . Ofivine in equilibrium with paremtal komatilite hiquid in Columin 1. 3: Derivative silicate melt after $30.5 \%$ FC of Column 1. 4: Bulk fractionated solid (olivine) after $30.5 \%$ FC of Column 1. 5: Derivative silicate melt after $55.5 \% \mathrm{FC}$ of Column 1 (estimated to be close to sulfide saturation). 6: Butk fractionated solid (oliwine + minor chromian spincl) after 50.5\% FC modeling of Column 1. 7: Average siliceous metasediment at Kambalda (Bavinton \& Keays 1978, Bavinton \& Taylor 1980, Bavinton 1981). 8: Sulfide component of Column 3, assuning all metals are hosted by the sulfide phase. 9: Average ocellite at Kambalda (Frogt \& Groves 1989; CM. Lesher \& R.R. Keays, unpubl. data). 10 : Average mafic metasediment at Kambalda (Bavinton \& Keays 1978, Bavinton \& Taylor 1980, Bavinton 198L). 11: Range of Kanbalda ore compositions (Ross \& Keays 1979, Keays et al. 1981, Cowden et al 1985, Cowden \& Woolnich 1987). * Sulfide magna'silicate magma partition coefficients taken fiom Lesher \& Camplell (1993), Lesher \& Stone (1996), and Mathex (1999); $\mathrm{D}_{\mathrm{zn}}{ }^{\text {sursa }}$ is entimated from model (ses explanatian in text). ** Silicate xenotnelt. / silicate magma, restite / silicate magma, and bulk solid / silicate magma partition-coeficicients caloulated from the compositions in this Table; $\mathrm{D}_{\mathrm{ib}}$ is assumed to be equal to $\mathrm{D}_{\mathrm{H}-\mathrm{r}}$

The mass proportions of xenomelt, restite, and solid phases likely varied with time and location in the system (see below), but can be estimated in general terms (Appendix). For example, the ores at Kambalda have been estimated to average $1 \mathrm{~m}$ in thickness (on a $100 \%$ sulfide basis) and to cover $\sim 10 \%$ of the basal contact of the Kambalda Komatiite Formation (Lesher et al. 1981). The contact metasedimentary rocks are up to $3 \mathrm{~m}$ thick $500 \mathrm{~m}$ away from the ore zones, but thin rapidly toward the ore zones, grading through chloritic sedimentary units to massive chloritites toward the ore zones (Fig. 1), defining an ore- and sediment-free "void zone" that is in some cases greater and in others smaller in width than the width of the ores zones (Bavinton 1979). Silicate xenomelts (felsic ocellites) are only rarely preserved (Frost \& Groves 1989; Fig. 1), but wholesale assimilation of a sediment containing an average of $7.6 \%$ sulfur (Bavinton 1981) and therefore $\sim 20 \%$ sulfides would have generated a mass of silicate xenomelt approximately four times the mass of sulfide xenomelt. The amount of cumulus olivine in the host units ranges between 35 and $65 \%$, but textural and chemical variations indicate that most of it crystallized after the ores (Lesher
1983, 1989). Nevertheless, the ore zones contain abundant net-textured and disseminated sulfides, indicating that at least some olivine was present. If we assume that 0.5 mass units of olivine crystallized for each mass unit of sediment melted and assimilated (Lesher \& Arndt 1995, Williams et al. 1998, 1999a), then the sulfide : xenomelt : restite : olivine proportions average 1: 4 : $0.5: 7$ (see Appendix). Although there are many uncertainties in this parameterization, it provides a basis for considering all of the potential components in the system.

Several models are presented in Figures 2-4, identified in terms of the relative mass-ratios of sulfide : silicate xenomelt : restite : silicate solid. The first model $\left(1: 0: 0: 0, Y^{0}=0\right)$ represents incorporation of barren $S$ and is equivalent to using Equation 2. The second model $\left(1: 0: 0: 60, Y^{0}=0\right)$ represents crystallization of olivine and sulfide in cotectic proportions (Duke 1986) and is equivalent to using Equation 1. The remaining model represents melting of metal-bearing sediments $(20 \%$ sulfide, $70 \%$ felsic miscible components, and $10 \%$ mafic residual components: see Appendix) with variable amounts of olivine crystallization. 

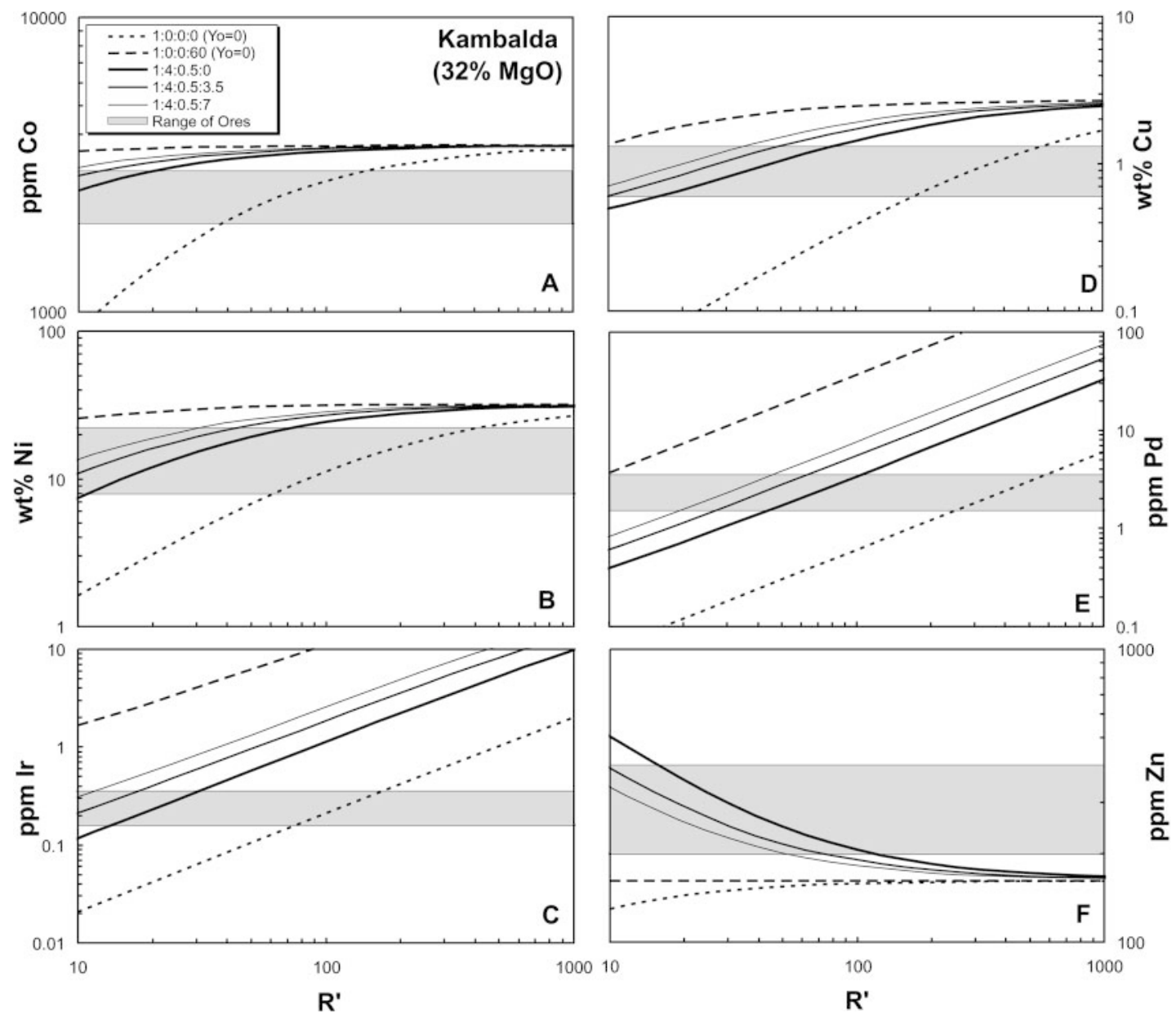

FIG. 2. Mass-balance models for $\mathrm{Co}, \mathrm{Ni}, \mathrm{Ir}, \mathrm{Cu}, \mathrm{Pd}$, and $\mathrm{Zn}$ in Kambalda sulfide ores as a function of mass fraction of silicate magma (R') calculated using Equation 5 in the text and the parental magma composition (Column 1 in Table 3). Models are labeled in terms of the relative mass-proportions of sulfide : xenomelt : restite : olivine. Ranges for Kambalda ores are given in Table 3.

The results of the models can be summarized as follows:

1. The metal contents of the ores (and all other phases: see Lesher \& Burnham 1999) decrease with decreasing mass-fraction of silicate magma (R'). This is, of course, the point originally made by Campbell \& Naldrett (1979): phases with high partition-coefficients that equilibrate with smaller amounts of silicate magma will have lower metal contents than phases with high partition-coefficients that equilibrate with larger amounts of silicate magma. The degree of depletion and the R' factor required to produce a significant amount of depletion both decrease in magnitude with decreasing magnitude of the partition coefficient: $\mathrm{D}_{\mathrm{Co}}{ }^{\text {Sul/Sil }}<$ $\mathrm{D}_{\mathrm{Ni}}{ }^{\text {Sul/Sil }}<\mathrm{D}_{\mathrm{Cu}}^{\text {Sul/Sil }} \ll \mathrm{D}_{\mathrm{PGE}}$ Sul/Sil .
2. Adding phases to the system changes the mass balance. Unless a metal alloy with a very high $D$ is involved, the addition of phases lowers the bulk partitioncoefficient, resulting in less depletion in the sulfide magma with decreasing mass-fraction of silicate magma (R'). Thus, a highly compatible element, which would normally be expected to be strongly depleted with decreasing R', is less depleted at a given R' if other phases are present. Although the magnitude of the effect depends on the partition coefficients of the phases and the relative abundances of the phases, it affects all elements in a similar fashion.

3. Campbell \& Barnes (1984) showed that if $\mathrm{R}<$ $D_{\text {PGE }}$ Sul/Sil $/ 10$, then $Y_{i}$ approaches $X_{i}{ }^{0} R$, and the composition of the sulfide magma is controlled by $\mathrm{X}_{\mathrm{i}}{ }^{0}$ and 
$\mathrm{R}$ (see Eq. 1 and 2). Because $\mathrm{D}_{\mathrm{PGE}}{ }^{\mathrm{Sul} / \mathrm{Sil}}$ values are so high $\left(10^{3}-10^{5}\right.$ : see reviews by Lesher \& Stone 1996 , Mathez 1999), calculations of $\mathrm{R}$ from $\mathrm{Y}_{\mathrm{PGE}}^{\mathrm{f}}$ based on Equations 1 or 2 are not sensitive to uncertainties in $\mathrm{D}_{\mathrm{PGE}}{ }^{\mathrm{Sul} / \mathrm{Sil}}$. It is obvious from inspection of Equation 12, however, that the same is true of $\mathrm{R}^{\prime}$ if $\mathrm{D}_{\mathrm{PGE}} \mathrm{Xen}^{\mathrm{Xil}}$, $\mathrm{D}_{\mathrm{PGE}}{ }^{\mathrm{Res} / \mathrm{Sil}}$, and $\mathrm{D}_{\mathrm{PGE}}{ }^{\mathrm{Sol} / \mathrm{Sil}} \ll \mathrm{D}_{\mathrm{PGE}}{ }^{\text {Sul/Sil }}$ or if $\mathrm{Y}_{\mathrm{i}}^{0}+\mathrm{Z}_{\mathrm{i}}^{0}+$ $\mathrm{W}_{\mathrm{i}}{ }^{0}+\mathrm{Q}_{\mathrm{i}}{ }^{0}+\mathrm{S}_{\mathrm{i}}{ }^{0}<\mathrm{X}_{\mathrm{i}}{ }^{0}$. As discussed above, although some systems have not incorporated metals from contaminants, many have (Table 1).

4. The model involving incorporation of barren sulfides does not reproduce the observed $\mathrm{Zn}$ contents of the ores (Fig. 2f). Increasing $\mathrm{X}_{\mathrm{Zn}}{ }^{0}$ (and decreasing $\mathrm{X}_{\mathrm{Co}}{ }^{0}$ and $\mathrm{X}_{\mathrm{Ni}}{ }^{0}$ ) by using a more fractionated magma (Figs. 3, 4) increases $Y_{Z n}$, but does not account for the wide range in the $\mathrm{Zn}$ contents of the ores and yields values for $\mathrm{Y}_{\mathrm{Co}}{ }^{\mathrm{f}}$ and $\mathrm{Y}_{\mathrm{Ni}}{ }^{\mathrm{f}}$ that are too low. Increasing $\mathrm{D}_{\mathrm{Zn}}{ }^{\mathrm{Sul} / \mathrm{Sil}}$ to $\sim 6$ reproduces the entire range of ore compositions between $R^{\prime}$ factors of 10 and 1000 , but $D_{\mathrm{Zn}}{ }^{\text {Sul/Sil }}$ has been determined to be 0.1-0.5 (Shimazaki \& MacLean 1976), i.e., to partition $2-10 \times$ more strongly into the silicate magma compared to the sulfide magma. It is possible that the experimental conditions are not applicable to Kambalda and that $\mathrm{Zn}$ partitioned more strongly into sulfide magma than the silicate magma, but it is not clear that a partition coefficient as high as 6 is justified. We obviously need better constraints on $\mathrm{D}_{\mathrm{Zn}}$ Sul/Sil , but if it is less than 6 , the relatively high $\mathrm{Zn}$ contents of Kambalda ores (200-400 ppm: Cowden et al. 1986) require an external source. A value of 2.5 produces results that are compatible with the other elements.
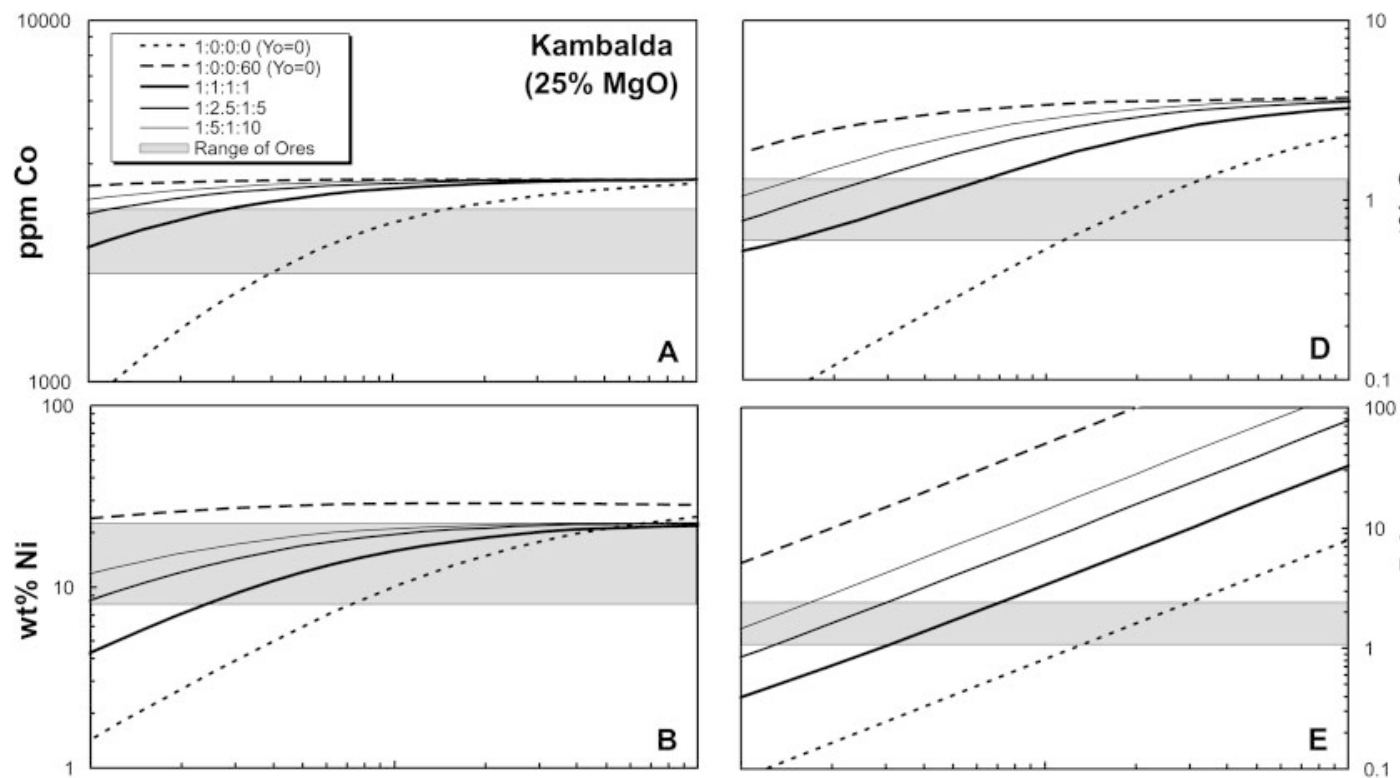

100
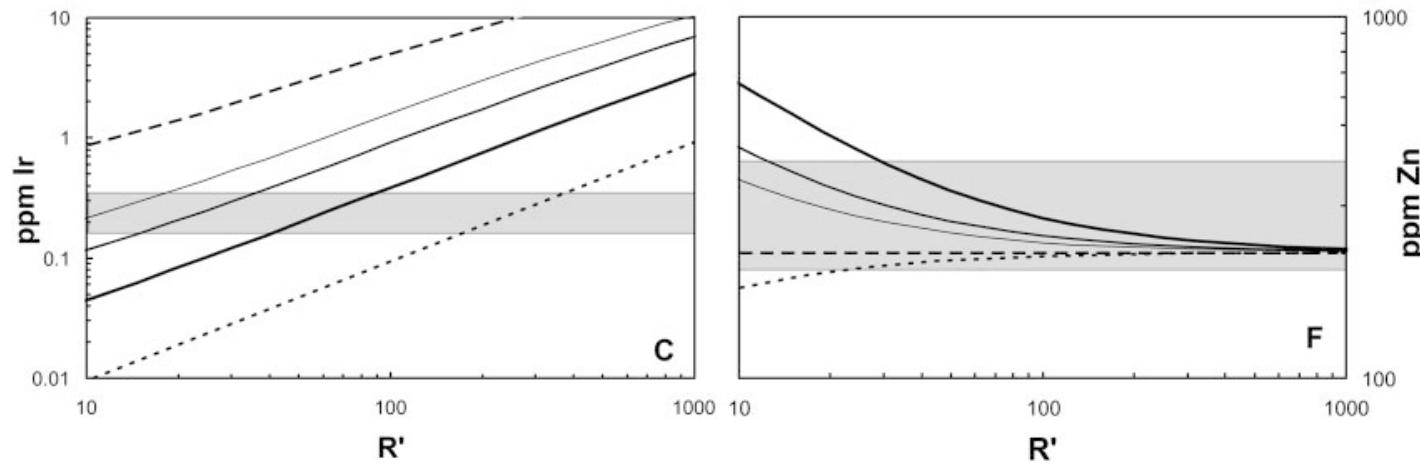

FIG. 3. Mass-balance models for $\mathrm{Co}, \mathrm{Ni}, \mathrm{Ir}, \mathrm{Cu}, \mathrm{Pd}$, and $\mathrm{Zn}$ in Kambalda sulfide ores as a function of mass fraction of silicate magma ( $\mathrm{R}^{\prime}$ ) calculated using Equation 5 in the text and a derivative parental magma composition containing $25 \% \mathrm{MgO}$ (Column 3 in Table 3). Models are labeled in terms of the relative mass-proportions of sulfide : xenomelt : restite : olivine. Ranges for Kambalda ores are given in Table 3. 

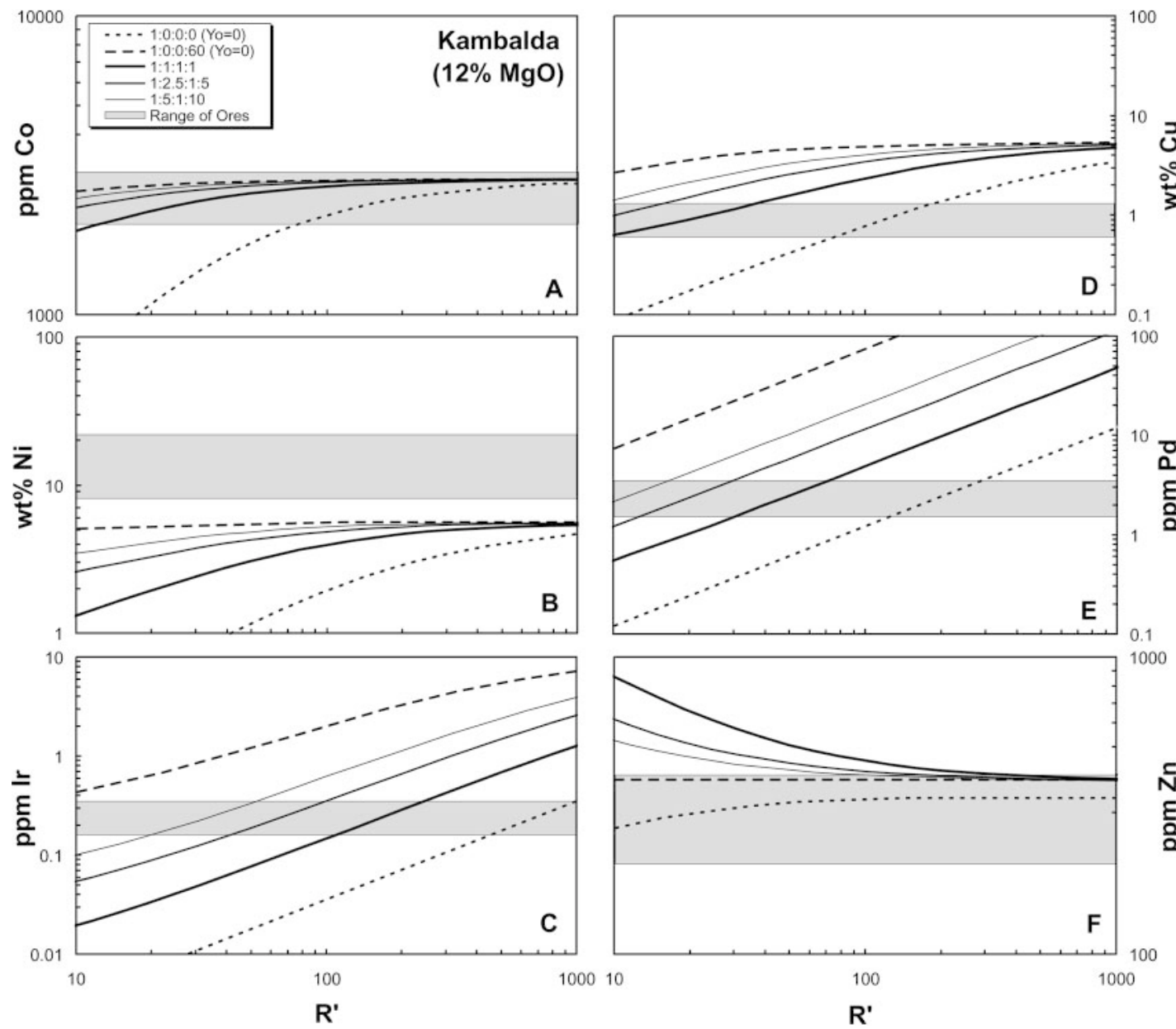

FIG. 4. Mass-balance models for $\mathrm{Co}, \mathrm{Ni}, \mathrm{Ir}, \mathrm{Cu}, \mathrm{Pd}$, and $\mathrm{Zn}$ in Kambalda sulfide ores as a function of mass fraction of silicate magma (R') calculated using Equation 5 in the text and a derivative magma composition containing $12 \% \mathrm{MgO}(\mathrm{Column} 5$ in Table 3). Models are labeled in terms of the relative mass-proportions of sulfide : xenomelt : restite : olivine. Ranges for Kambalda ores are given in Table 3.

5. The model involving segregation of olivine and sulfide in cotectic proportions (60:1) results in only a very minor change in $\mathrm{Y}_{\mathrm{Ni}}^{\mathrm{f}}, \mathrm{Y}_{\mathrm{Co}}^{\mathrm{f}}$, and $\mathrm{Y}_{\mathrm{Zn}}^{\mathrm{f}}$ (and also $\mathrm{X}^{\mathrm{f}}$, $\mathrm{W}^{\mathrm{f}}, \mathrm{Q}^{\mathrm{f}}$, and $\mathrm{S}^{\mathrm{f}}$ for the same elements) over a very wide range of R', and a minor change in $\mathrm{Y}^{\mathrm{f}} \mathrm{Cu}$ at low $\mathrm{R}$ ', but a significant change in $\mathrm{Y}^{\mathrm{f}}{ }_{\mathrm{Pd}}$ and $\mathrm{Y}_{\mathrm{Ir}}^{\mathrm{f}}$ over the same range. This is because $D_{\mathrm{Zn}}$ Sul/Sil $<D_{\mathrm{Co}}$ Sul/Sil $<D_{\mathrm{Ni}^{\text {Sul/Sil }}}<<$ $\mathrm{D}_{\mathrm{Cu}}{ }^{\text {Sul/Sil }} \ll \mathrm{D}_{\mathrm{PGE}}{ }^{\text {Sul/Sil }}$. As noted above, the effect of crystallizing abundant olivine with sulfide is to reduce the bulk partition-coefficient and to decrease the relative influence of R'. For example, the bulk partitioncoefficient for a $60: 1$ mixture of olivine $\left(\mathrm{D}_{\mathrm{Ni}} \mathrm{Sol} / \mathrm{Sil}\right.$ in the range 1-2) and sulfide $\left(\mathrm{D}_{\mathrm{Ni}}{ }^{\text {Sul/Sil }}\right.$ in the range $\left.100-200\right)$ is 2.6-5.2, i.e., 38-47× smaller than $\mathrm{D}_{\mathrm{Ni}}$ Sul/Sil . Although this model may be applicable for disseminated $\mathrm{Ni}-\mathrm{Cu}-$ (PGE) sulfide deposits like Mt. Keith (Groves \& Keays 1979) or Dumont (Eckstrand 1975, Duke 1986), there are many geological, geochemical, thermodynamic, and fluid-dynamic arguments against internal derivation of the massive sulfide ores at Kambalda (Lesher \& Groves 1986, Lesher 1989). The limited range of ore compositions that would result from cotectic segregation of olivine and sulfide provides further support that this is not a viable mechanism for producing the observed compositional range of Kambalda ores.

6. The model designed to simulate the relative masses of ores, residues, and olivine in the ore environment at Kambalda (1:4:0.5:7) yields the lowest values 
of R'. It can only be excluded on the basis that it predicts Ir (and therefore also Os) abundances higher than those in the ores (Fig. 1c).

7. The models that include less olivine $(1: 4: 0.5: 3.5$ and $1: 4: 0.5: 0)$ provide reasonable results for all of the elements. This agreement suggests that the capacity of the lava to incorporate and dilute those components without crystallizing olivine may have been greater than expected.

There is no unique solution, as there are too many uncertainties and too many variables, but it is clear that the extra components must be included.

\section{Isotopic variations at Kambalda}

The parameters used in the models are given in Table 3. The $\mathrm{S}$ isotopic data and $\mathrm{S} / \mathrm{Se}$ values are from Donnelly et al. (1978), Groves et al. (1979), and Seccombe et al. (1981). The Os isotopic data are taken from Foster et al. (1996). We assume that the komatiitic magmas have a chondritic $S / S e$ value and chondritic $S$ and Os isotopic compositions $\left(\mathrm{S} / \mathrm{Se} \approx 3333, \delta^{34} \mathrm{~S} \approx 0 \%\right.$, $\gamma \mathrm{Os} \approx 0)$ and that the $\mathrm{S} / \mathrm{Se}$ values and $\mathrm{S}$ and Os isotopic compositions of the various components of the contaminants are identical $\left(\mathrm{S} / \mathrm{Se} \approx 20,000, \delta^{34} \mathrm{~S} \approx+4 \%\right.$ o, $\gamma \mathrm{Os} \approx$ +900).

Several models are presented in Figure 5, identified as above in terms of the relative mass proportions of sulfide : silicate xenomelt : restite : silicate solid. The results of the models can be summarized as follows:

1. In the absence of a S-bearing contaminant, $\gamma_{\mathrm{Os}}$, $\delta^{34} \mathrm{~S}$ and $\mathrm{S} / \mathrm{Se}$ do not vary with the mass fraction of silicate magma ( $\mathrm{R}^{\prime}$ ) and preserve the composition of the magma. This applies specifically to the models parameterized to represent fractional segregation of sulfide with or without crystallization of olivine.

2 . For systems involving the addition of a sulfurbearing contaminant, $\gamma_{\mathrm{Os}}, \delta^{34} \mathrm{~S}$ and $\mathrm{S} / \mathrm{Se}$ increase with decreasing mass-fraction of silicate magma ( $\mathrm{R}^{\prime}$ ), reflecting an increase in the relative contribution from the crustal component.

3. Because Os and $\mathrm{S}$ are present in such different abundances, the variations in $\gamma_{O s}$ are quite different from the variations in $\delta^{34} \mathrm{~S}$ and $\mathrm{S} / \mathrm{Se}$ ratio. With all else equal, an element like Os, which is a trace element in the sulfide magma and an ultra-trace element in the silicate
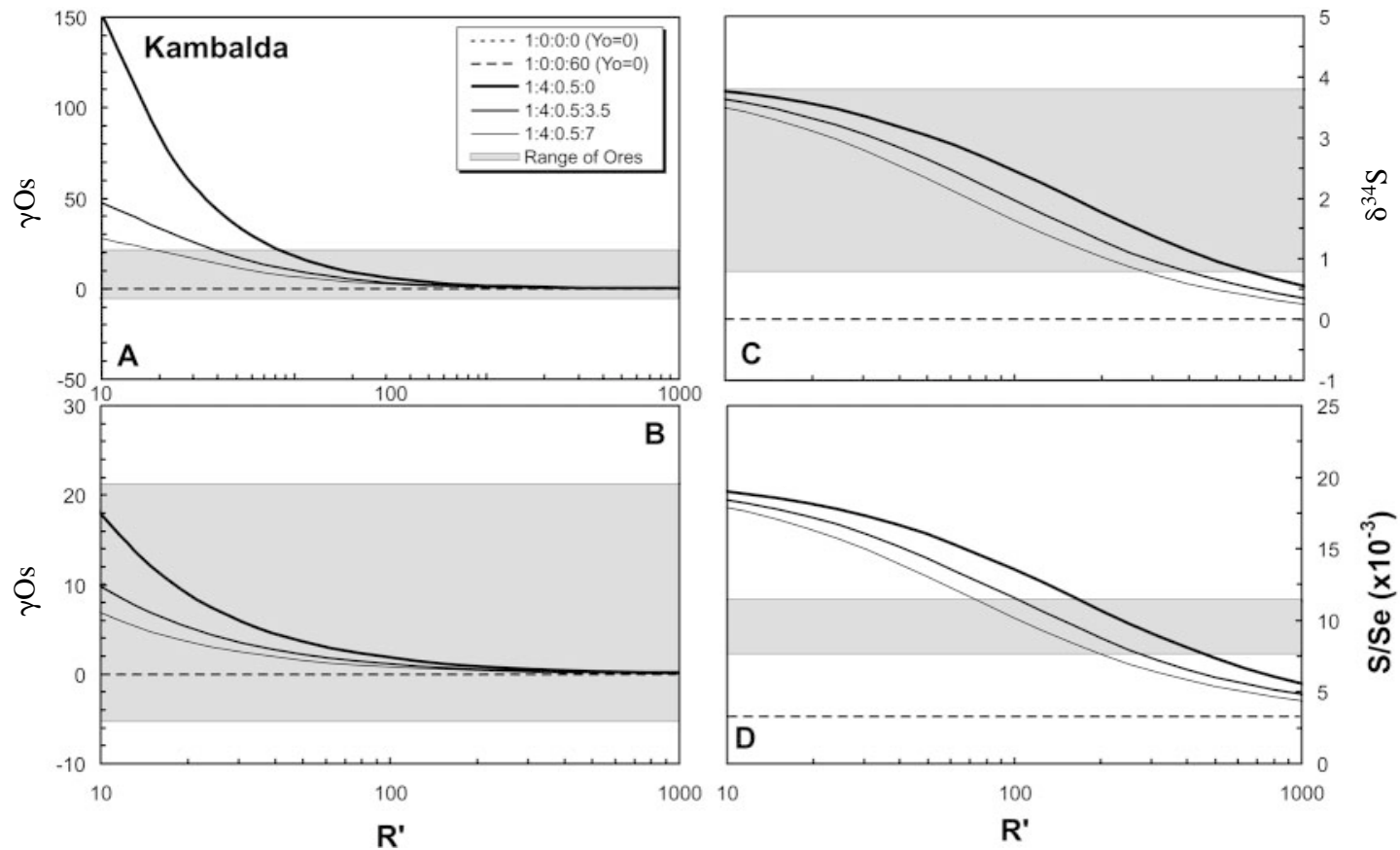

FIG. 5. Mass-balance models for $\gamma \mathrm{Os}, \delta^{34} \mathrm{~S}$, and $\mathrm{S} / \mathrm{Se}$ in Kambalda sulfide ores as a function of mass fraction of silicate magma ( $\left.\mathrm{R}^{\prime}\right)$ calculated using Equation 5 in the text and the parental magma composition (column 1 in Table 3). Models are labeled in terms of the relative mass-proportions of sulfide : xenomelt : restite : olivine. The 1:0:0:0 and 1:0:0:60 models (i.e., fractional crystallization of sulfide and fractional crystallization of sulfide + olivine in the absence of any contamination) both produce zero variation in $\gamma_{O s}, \delta^{34} \mathrm{~S}$, and $\mathrm{S} / \mathrm{Se}$ with changing $\mathrm{R}$ '. 
magma, will be a less sensitive indicator of crustal contamination than an element like $\mathrm{S}$, which is a major element in the sulfide magma and a trace element in the silicate magma. Lithophile isotopic systems such as $\mathrm{Sr}$ and $\mathrm{Nd}$ are even more sensitive indicators of crustal contamination than Os, owing to their greater abundances in the contaminant relative to the silicate or sulfide magmas (Lesher \& Stone 1996, Lesher et al. 1999b, Ripley et al. 1999a).

4. Adding phases to the system changes the mass balance and, in most cases (i.e., unless a phase with a very high $\mathrm{D}$ and therefore very high abundance is involved), dilutes the contaminant. This results in less enrichment (e.g., $\gamma_{\mathrm{Os}}, \delta^{34} \mathrm{~S}$, or $\left.\varepsilon_{\mathrm{Sr}}\right)$ or depletion (e.g., $\varepsilon_{\mathrm{Nd}}$ ) with decreasing mass-fraction of mafic or ultramafic magma (R'). Thus, an isotopic signature that would normally be expected to be strongly enriched or depleted with decreasing R' is less enriched or depleted at a given $\mathrm{R}$ ', thus reducing the apparent degree of contamination at a given mass-fraction of mafic or ultramafic magma.

The proportions of non-sulfide phases are even larger at other deposits. Virtually all magmatic $\mathrm{Ni}-\mathrm{Cu}-(\mathrm{PGE})$ deposits exhibit some evidence of contamination (Table 1), virtually all contain abundant olivine showing geochemical evidence of interaction with sulfides (see summaries by Naldrett 1989, Lesher \& Stone 1996), some contain very large masses of inclusions (e.g., Voisey's Bay: Li \& Naldrett 2000), and some are surrounded by very large metasomatic aureoles (e.g., Noril'sk: Naldrett et al. 1995). Thus, we should expect to see an equally large influence at other deposits.

\section{DISCUSSION}

The mixing calculations show that the metal contents and isotopic compositions of magmas, sulfides, silicate xenomelts, restites, and crystalline solids that have equilibrated through a batch-equilibration process in ore-forming magmatic systems vary with contrasts in elemental abundances, isotopic ratios, and mass proportions. How much information can be obtained from such calculations depends on how closely they simulate the ore-forming process and how well the models are parameterized.

\section{Xenoliths, xenomelts, xenovolatiles, and restites}

Country-rock xenoliths and xenomelts are rare in most komatiite-associated $\mathrm{Ni}-\mathrm{Cu}$-(PGE) sulfide deposits (Table 1), presumably because of the very high temperatures and very low viscosities of the lavas or magmas, which promote rapid dissolution (see Williams et al. 1998, 1999a). In contrast, xenoliths are abundant to ubiquitous in basalt-associated $\mathrm{Cu}-\mathrm{Ni}$-(PGE) sulfide deposits (Table 1), presumably because of the lower temperatures and higher viscosities of the magmas. Thus, it is essential to consider these phases when per- forming metal- and isotope-based mass-balance calculations.

The models in this paper represent the initial contaminant as a mixture of three phases (Table 3): 1) a sulfide component, which is assumed to be largely immiscible, 2) a silicate component, which is normally incorporated into the mafic or ultramafic magma, and 3) a restite component. The compositions of these components can be estimated by "disassembling" the initial contaminant. Alternatively, they may be calculated by inverting the mass-balance equations, and solving for $\mathrm{Y}_{\mathrm{i}}{ }^{0}, \mathrm{Z}_{\mathrm{i}}{ }^{0}$ or $\mathrm{Q}_{\mathrm{i}}{ }^{0}$. Although terms have not been specifically added for a xenovolatile phase in this paper, because of uncertainties in establishing the composition of such a phase, $\mathrm{S}$ and metals are known to partition into a vapor phase (Candela \& Piccoli 1998), and it may be desirable to add appropriate terms for a volatile phase in certain situations.

The inclusion of a restite component in these models is particularly important, because the components in the restite will not be incorporated into the silicate magma or the sulfide magma, which leads to very different mass-balances compared to models that assume wholesale assimilation. Restites seem to be present in most deposits (Table 1), where they are represented by contact-metamorphic zones, skarns, xenoliths, and other types of partially melted or decomposed wallrocks. For example, 1) Bavinton \& Keays (1978) have shown that the mafic metasedimentary units at Kambalda (interpreted here as restites) are enriched in many metals including Ir (and therefore probably also Os), 2) Ripley \& Alawi (1988) have shown that the compositions of the host rocks in the Duluth Complex vary widely in proximity to country-rock inclusions, 3) Lesher \& Arndt (1995) have inferred that some of the compositional and isotopic variations in the host units at Kambalda may be attributable to incomplete mixing of xenomelts, and 4) Arndt et al. (1998) have shown that the xenoliths at Noril'sk-Talnakh contain more radiogenic $\mathrm{Sr}$ than the wall rocks. In what is probably the most comprehensive study of this type, Ripley et al. (1999a) noted that the xenoliths in the Duluth Complex had undergone partial melting, but that no isotopic evidence of this was preserved, probably owing to the buoyancy of the partial melt and convection in the chamber. Although there are considerable uncertainties in establishing the masses of xenoliths, xenomelts, and restites, these studies highlight the importance of including terms for those components in the mass-balance calculations.

\section{Dynamics of ore-forming magmatic systems}

Natural systems are considerably more complex than any of these mathematical models. The analyzed components have interacted with each other and with multiple other components present in variable proportions in different ways at different times, and therefore repre- 
sent the integrated product of multiple processes, including fractional crystallization, batch equilibration, and zone refining. This complexity limits our ability to model the ore-forming process in several ways:

1. The mass-conservation equations in this paper are strictly applicable only in closed systems where two phases initially not in equilibrium are allowed to equilibrate; they assume that $\mathrm{A}^{\mathrm{o}}=\mathrm{A}^{\mathrm{f}}, \mathrm{B}^{\mathrm{o}}=\mathrm{B}^{\mathrm{f}}$, etc., and therefore that $R^{o}=R^{f}$. This situation is achieved when, for example, a sulfide-saturated silicate magma interacts with a sulfide magma in a closed system and where the composition of the magma does not change with time. However, as noted by Lesher \& Campbell (1993) and discussed below, it is possible for the magma to be initially undersaturated in sulfide, in which case it will dissolve some of the sulfide. In this case, $A^{o} \neq A^{f}, B^{o} \neq B^{f}$, etc. and $\mathrm{R}^{\mathrm{o}} \neq \mathrm{R}^{\mathrm{f}}$. However, as long as the system remains closed, or closed on the scale of parameterization, the equations remain valid. It is possible to derive analytical solutions for open-system equilibration (e.g., "zone refining": Pfann 1952, Harris 1957, see also Brügmann et al. 1993), but the results for compatible elements are fundamentally similar to those for batch equilibration (see discussion by Lesher \& Stone 1996). Systems that are truly open, in which A, B, C, D, and E, and therefore $R$, vary with space and time, must be modeled numerically.

2. As discussed by Lesher \& Campbell (1993), if the system is closed (or viewed as closed on a large scale), the composition of the sulfide will be determined by the initial composition of the lava or magma. If the system is open and sulfides re-equilibrate with replenished lava or magma, they will have a composition similar to that expected in the closed system at an equivalent $\mathrm{R}$ (or, in this case, $\mathrm{R}^{\prime}$ ). If the system is open and sulfides are removed "upstream" in the system, the compositions of newly generated sulfides will be determined by the composition of the evolved lava. Depending on the abundances of the components relative to the normal fractionation-induced trajectory of the lava, contamination may enhance or partially offset the effects of sulfide segregation (Lesher \& Campbell 1993, Lesher \& Stone 1996, Lesher et al. 1999b, 2001).

3 . It is commonly very difficult to establish the end members of the system. Initial compositions are in many instances estimated from rocks that seem to be uncontaminated and least-fractionated and to represent reasonable parent and daughter products. However, such estimates are not valid in every case, unless the lava or magma is derived from a long-term, homogeneous source by a process in which the lava or magma composition remains otherwise constant. In some cases, it is possible to identify closely associated rocks that have crystallized from replenished lavas or magmas (see discussion by Lesher \& Arndt 1995, Lesher \& Stone 1996, Lesher et al. 1999b, 2001), but in many cases there is no direct evidence of the parent.
4. In cumulate systems, the final compositions of liquid components of the system may in some cases only occur at significant distances "downstream" in the volcanic or magmatic plumbing system (e.g., Brügmann et al. 1993); where not exposed, the final compositions must be estimated from the compositions of the cumulate rocks. This is less problematic for isotopic components, which are normally expressed as ratios and are commonly assumed to have been in equilibrium in all phases of the rock, but it is much more problematic for individual elements.

5. Many components, including $\mathrm{C}, \mathrm{S}$, and Os, are volatile under oxidizing conditions, and may be lost during an ore-forming process that involves melting of unconsolidated sediments on the seafloor. Os is so volatile under oxidizing conditions that many PGE laboratories do not report data for Os, and nearly all Os isotope laboratories now perform the dissolutions in sealed glass tubes (Shirey \& Walker 1995). Significant amounts of Os and S may have been lost during ore formation, and this may have been more significant for an ultra-trace component like Os than for a major element like $S$.

6. Natural systems are rarely in perfect equilibrium, and this is especially true of dynamic ore-forming systems. Thus, $\mathrm{R}$ and $\mathrm{R}$ ' represent effective mass-fractions, which may vary from element to element and isotopic system to isotopic system. Devolatilization, partial melting, liquid immiscibility, and crystallization may all result in incomplete incorporation of components from the contaminant, or incomplete equilibration between the magma and the contaminant, or both. Although isotopic equilibration is more likely at high temperatures, $\mathrm{Sr}$ isotopes commonly exhibit disequilibrium between phenocrysts and groundmass (e.g., Duffield \& Ruiz 1998) and Os isotopes require extraordinary measures to ensure equilibration between sample and spike during preparation for mass spectrometric analysis (e.g., Shirey $\&$ Walker 1995). Disequilibrium can be simulated by modifying the elemental abundances or partition coefficients in Equations 11-15 or the elemental abundances and isotopic ratios in Equations 16 and 17.

\section{Decoupling $A, B, C, E$, and $F$}

There are many ways in which the mass fractions of silicate magma (A), sulfide magma (B), xenomelt or xenovolatiles $(\mathrm{C})$, restite $(\mathrm{E})$, and crystalline solid $(\mathrm{F})$ may become decoupled, resulting in variable $\mathrm{A} / \mathrm{B}, \mathrm{A} / \mathrm{C}$, $\mathrm{A} / \mathrm{E}, \mathrm{A} / \mathrm{F}$, and $\mathrm{R}$ ' values. We may envision this by considering several different cases:

1. Sulfide-saturated magma: If a lava or magma is emplaced at its liquidus temperature and at or near sulfide saturation, which is more likely for basaltic magmas than komatiitic magmas (see discussion by Lesher \& Groves 1986, Naldrett \& Barnes 1986, Keays 1995), it may, under favorable fluid-dynamic and thermodynamic circumstances (see discussion by Williams et al. 
1998, 1999a) melt S-bearing country rocks, crystallize a solid, and generate a silicate melt (which may or may not dissolve), a sulfide melt (which will not dissolve), and possibly a restite. The mass fractions of sulfide melt, silicate xenomelt, restite, and crystalline solid will increase, and the mass fraction of silicate magma will decrease with increasing cooling of the magma and melting of the country rocks through the process of assimilation - fractional crystallization (AFC). Thus, R' and the mass fractions of the other components will change with time.

2. Sulfide-undersaturated magma: If a lava or magma is emplaced at its liquidus temperature but well below sulfide saturation, which is more likely for komatiitic magmas than basaltic magmas (see references above), it will, under similar circumstances, melt S-bearing country rocks, crystallize a solid, and generate a silicate melt (which may or may not dissolve), a sulfide melt (which will immediately dissolve), and possibly a restite. Consequently, the mass fraction of silicate melt and solid will increase and the mass fraction of lava or magma will decrease with increasing degree of assimilation - fractional crystallization (AFC) until the lava or magma becomes saturated in sulfide, at which point the mass fraction of sulfide will also increase with increasing AFC.

3. Superheated, sulfide-undersaturated magma: If a lava or magma is emplaced at a supraliquidus temperature (see discussion by Lesher \& Groves 1986, Barnes et al. 1995, Williams et al. 1999a) and well below sulfide saturation, it will, under similar circumstances, melt S-bearing country rocks and generate a silicate melt (which may or may not dissolve), a sulfide melt (which will dissolve), and possibly a restite, but it will not immediately crystallize a solid. Consequently, the mass fraction of silicate melt will increase and the mass fraction of lava or magma will decrease with increasing degree of assimilation until the lava or magma reaches the silicate liquidus, at which point the mass fraction of solid silicate will increase with increasing AFC, until the lava or magma becomes saturated in sulfide, at which point the mass fraction of sulfide will increase with increasing AFC.

4. Remelted sulfides: If flow rates decline and thermal erosion ceases, the lava or magma may continue to crystallize a solid, to precipitate small amounts of sulfide, and to react with the sulfide magma, silicate xenomelt, restite, and crystalline solid, but no new contaminants will be added. If the lava or magma in the system is replenished by uncontaminated, sulfide-undersaturated lava or magma, which appears to have been the case at Kambalda (Lesher \& Arndt 1995; see also Lesher et al. 1999b, 2001), the silicate magma may redissolve some of the other components, particularly sulfides, which will decrease the mass fraction of sulfide (Lesher \& Campbell 1993).

5. Xenomelts and xenovolatiles: Detailed studies in many deposits (references in Table 1) indicate that melt- ing was focused in specific parts of lava channels and magma conduits and that the degree of interaction between the lava or magma and the country rocks was locally quite variable. Xenomelts or xenovolatiles derived from country rocks are particularly vulnerable to being mixed into the magma, resulting in variable degrees of incorporation of different components in different parts of the system.

Parameterizing each of these cases using the compositions and proportions of the initial magma, the initial solid, and the initial silicate, sulfide, and residual components of the contaminants will ensure that mass is conserved. However, it will overestimate the mass fraction of sulfide in Case 2, it will overestimate the mass fractions of solid and sulfide in Case 3, it will underestimate the mass fraction of sulfide in Case 4, and it will average the variable mass-fractions of the xenomelt or xenovolatile phase in Case 5 . Case 2 is most appropriately modeled as a two-stage process, the first stage involving contamination with crystallization, the second stage involving contamination and crystallization with sulfide segregation. Case 3 is most appropriately modeled as a three-stage process, the first stage involving contamination without crystallization, the second stage involving contamination with crystallization, and the third stage involving contamination and crystallization with sulfide segregation. The influence of using different parameterizations can be seen in Table 3. A parental magma that initially contains $\sim 2.1 \mathrm{ppb} \mathrm{Ir}$ will be in equilibrium with a solid containing $\sim 7.0 \mathrm{ppb}$ Ir, but will fractionate to $\sim 0.36 \mathrm{ppb}$ Ir prior to reaching sulfide saturation, producing a bulk solid containing $\sim 3.8 \mathrm{ppb}$ Ir (Table 3). The use of derivative compositions in the mixing calculations will produce quite different results compared to the use of initial compositions.

Note that this approach is slightly different than that employed by Lambert et al. (1998b). They appear to have followed Lesher \& Stone (1996) and to have used Equation 7 for their mixing calculations, but they mixed the metals in the contaminant and lava without including the metals incorporated in olivine ( $c f$. their equations 1 and 2), and they used Equation 1 (rather than Equations 2 or 5) to distribute the metals between the silicate and sulfide magmas. As discussed above, unless the magma is superheated, contamination of a komatiitic magma must be accompanied by crystallization of olivine, and Equation 1 is strictly valid only for systems in which the $\mathrm{S}$ and metals are derived internally.

\section{Decoupling of elements and isotopes}

Geochemical and isotopic studies indicate that the elemental and isotope geochemistry of magmas and ores that have formed or have become modified in a dynamic magmatic system can vary considerably depending on the compositions of the magma, contaminant, and ore, the relative masses of magma, contaminant, and ore, and 
the nature and degree of assimilation. As discussed by Lesher \& Groves (1984), Lesher \& Campbell (1993), Barnes et al. (1995), Lesher \& Arndt (1995), Lesher \& Stone (1996), Perring et al. (1996), and Lesher et al. (1999b, 2001), these parameters may vary both within and among ore-forming systems. Geochemical and isotopic data can provide important insights into ore-forming processes and can, under certain circumstances, identify magmas that have interacted with crustal (or crust-derived) rocks, but the geochemical and isotopic data must be interpreted within a proper geological framework.

Campbell \& Naldrett (1979), Lesher \& Stone (1996), Walker et al. (1997), and Ripley et al. (1999a) have shown that elements and isotopes with different relative abundances in magmas and crustal contaminants and different partition-coefficients between silicate magmas and sulfide magmas may decouple from each other in dynamic magmatic systems. The order of sensitivity of detection of crustal contamination at Kambalda seems to be $\mathrm{S} \approx \mathrm{Pb}>\mathrm{Nd}>$ Os (Lesher \& Stone 1996), at Raglan it seems to be $S>$ Os (Lesher \& Ripley 1992, Shirey \& Barnes 1994), at Noril'sk it seems to be $\mathrm{S}>\mathrm{Sr}>\mathrm{Os}$ (Grinenko 1985, Walker et al. 1994b, Arndt et al. 1998), at Pechenga it seems to be Os $>\mathrm{Nd} \approx \mathrm{Pb} \approx \mathrm{S}$ (Hanski 1992, Walker et al. 1997), and at Duluth it seems to be $\mathrm{C}>\mathrm{S}>\mathrm{Nd}>\mathrm{Pb} \approx \mathrm{Os}$ (Ripley et al. 1999a). The results are unique in each case depending on the contrasts in abundances and isotopic ratios of the various components of the system.

Different elements and isotopes may also behave differently in different parts of the system, at different times. For example, the magma may interact with various components of continental crust on the way up and selectively incorporate those components that are enriched in continental crust, for example $\mathrm{Sr}$, but very little of those components that are depleted in continental crust, for example Os. Then, during ore formation, the magma may selectively incorporate those components that are least stable during partial melting or devolatilization, for example $\mathrm{S}$ in sediments, but very little of those components that are stable during partial melting or devolatilization, for example $\mathrm{Sr}$, which may be retained in skarns, or Os, which may be retained in mafic residues. The point is that the origin of the $\mathrm{Sr}$ or Os in the ore or host rock may have nothing to do with the source of the $S$ in the ores. Of course, the same principles apply to other types of ore deposits where a hydrothermal fluid may selectively extract $\mathrm{Pb}$ from one source, $\mathrm{Sr}$ from another source, and metals from yet a different source.

\section{Implications for the genesis of $\mathrm{Ni}-\mathrm{Cu}-(\mathrm{PGE})$ deposits}

The results provide additional constraints on the genesis of the $\mathrm{Ni}-\mathrm{Cu}-(\mathrm{PGE})$ sulfide mineralization at Kambalda:
1. Contrary to the interpretations of Foster et al. (1996) and Lambert et al. (1998a, b, 1999b), the Os isotopic signatures of Kambalda ores do not preclude a ground-melting model. Osmium is simply not abundant enough in the sediment for contamination to be resolvable except at extremely low mass-fractions of silicate magma, especially when one includes the olivine, xenomelts, and residues that also must have been present. In any case, Os isotopes can only provide information about the source(s) of the Os in the ores. They provide only indirect information, at best, about the source(s) of the $\mathrm{S}$ in the ores.

2. Foster et al. (1996) and Lambert et al. (1998a, b, $1999 b$ ) argued that $S$ may have been mobile, which might explain why the $\mathrm{S}$ isotopic compositions of the ores are similar to those of the metasediments. There is evidence of $\mathrm{S}$ addition in some ores, but no evidence that the majority of the ores have had their $\mathrm{S}$ isotopic compositions reset (Seccombe et al. 1981).

3. Foster et al. (1996) and Lambert et al. (1998a, b, 1999 b) also argued that there is insufficient $S$ in the sediments, with reference to an argument by Gresham (1986). However, that interpretation was based on the interpretation that the ores and komatiites were erupted from feeder fissures beneath the ore zones, an interpretation that has subsequently been superseded by the interpretation that they formed in distal lava channels (Lesher et al. 1984). These authors used the present average (eroded) thickness of the metasediments rather than the present maximum (original) thickness (see discussion in Appendix). In fact, even if one does not permit the ores to include $\mathrm{S}$ incorporated upstream from their present locations, the amount of sulfide in the ore zones is less than that inferred to have been in the missing sediments, suggesting that some of the sulfide was dissolved by the lava (see discussion by Lesher \& Campbell 1993) or transported "downstream". Calculations of this type involve many uncertainties, of course, but there certainly does not appear to be any justification for arguing that the sediments do not contain enough $\mathrm{S}$.

4. The many geological, geochemical, thermodynamic, and fluid-dynamic arguments against exsolving the $\mathrm{S}$ from the lava during ascent or emplacement, as suggested by Foster et al. (1996) and Lambert et al. (1998a, b, 1999b), had been raised previously by Lesher \& Groves (1986), Lesher (1989), and Lesher \& Stone (1996). Any model that involves exsolution of sulfides from the magma must explain how a lava that was undersaturated in sulfide (Keays 1995) and probably contained only 500 ppm S (Lesher \& Stone 1996) could have exsolved millions of tonnes of sulfide ore without experiencing significant amounts of crystallization or depletion in chalcophile elements in the ores (Lesher \& Campbell 1993, this study) and host rocks (Lesher \& Arndt 1995, Lesher \& Stone 1996). 
5. Any model for Kambalda that does not involve incorporation of $\mathrm{S}$ from the sediments must explain why the sediments are missing from the "ore prism" (Gresham \& Loftus-Hills 1981), why the sediments grade from silica-rich to chlorite-rich to massive chloritites toward the ores zones (Bavinton 1979), why LREE-HFSE-enriched and chalcophile-element-depleted komatiites occur only in the adjacent sheet-flow facies of the host units (Lesher \& Arndt 1995, Lesher et al. 1999b, 2001), why the felsic ocellites have exactly the same chemical compositions as the silicate component of the metasediments and only occur in the sheetflow facies of the host units (Frost \& Groves 1989), and why the $\mathrm{S}$ isotope compositions of the ores at Kambalda (and virtually all other deposits of this type) are similar to those of the associated S-rich country rocks (Groves et al. 1979, Lesher 1989, Naldrett 1989).

A ground-melting model, involving wholesale melting beneath the lava channels and incongruent melting adjacent to the lava channels, appears to explain all of the geological, stratigraphic, mineralogical, geochemical, and isotopic evidence at Kambalda. It has also proven itself over time to be the most robust model for exploration of deposits of this type.

\section{Conclusions}

Ore-forming processes normally involve multiple components. The compositions and masses of all components must be considered when interpreting geochemical and isotopic data. In the case of magmatic $\mathrm{Ni}-\mathrm{Cu}-(\mathrm{PGE})$ deposits, it is critical to consider the influence of not only the magma or lava and the sulfide phase, but also the influence of xenomelts, xenovolatiles, xenoliths or residues, and crystalline solids. The presence of these additional phases can markedly influence the elemental and isotopic compositions of the ores and magmas.

\section{ACKNOWLEDGEMENTS}

We have benefitted greatly from discussions with many colleagues regarding various aspects of the material in this paper, including Sarah-Jane Barnes, Steve Barnes, Ian Campbell, Paul Golightly, Jeff Foster, David Groves, Chris Hawkesworth, Reid Keays, David Lambert, Peter Lightfoot, Tony Naldrett, Steve Shirey, and Ed Ripley. We are especially grateful to Ed Ripley, David Lambert, and Sarah-Jane Barnes for their very helpful reviews of the manuscript and to Robert F. Martin for his incisive editorial suggestions. This work has been supported at various stages by grants from the U.S. National Science Foundation (EAR-8820126, EAR9018938, and EAR-9405994) and the Natural Sciences and Engineering Research Council of Canada (IRC 663-001/97 and Operating Grant 203171/98), and has benefitted greatly from earlier work supported by Western Mining Corporation.

\section{REFERENCES}

Amelin, Y., Li, Chusi, Valeyev, O. \& NaldRett, A.J. (2000): $\mathrm{Nd}-\mathrm{Pb}-\mathrm{Sr}$ isotope systematics of crustal assimilation in the Voisey's Bay and Mushuau intrusions, Labrador, Canada. Econ. Geol. 95, 815-830.

ANDREws, M.S. \& RiPLEY, E.M. (1989): Mass transfer and sulfur fixation in the contact aureole of the Duluth Complex, Dunka Road Cu-Ni deposit, Minnesota. Can. Mineral. 27, 293-310.

Arndt, N.T., Czamanske, G.K., Walker, R.J., Chauvel, C. \& Fedorenko, V.A. (1998): Geochemistry and origin of the intrusive host rocks of Noril'sk-Talnakh Cu-Ni-PGE deposits. Eighth Int. Platinum Symp., Abstr., Geol. Soc. S. Afr., Symp. Ser. S18, 17-20.

BARNES, S.-J. \& MAIER, W.D. (1999): The fractionation of Ni, $\mathrm{Cu}$, and the noble metals in silicate and sulphide liquids. In Dynamic Processes in Magmatic Ore Deposits and their Application in Mineral Exploration (R.R. Keays, C.M. Lesher, P.C. Lightfoot \& C.E.G. Farrow, eds.). Geol. Assoc. Can., Short Course Notes 13, 69-106.

MelezhiK, V.A. \& Sokolov, S.V. (2001): The composition and mode of formation of the Pechenga nickel deposits, Kola Peninsula, northwestern Russia. Can. Mineral. 39, 447-471.

\& PICARD, C. (1993): The behavior of platinumgroup elements during partial melting, crystal fractionation, and sulphide segregation: an example from the Cape Smith fold belt, northern Quebec. Geochim. Cosmochim. Acta 57, 79-87.

Barnes, S.J., Hill, R.E.T. \& Gole, M.J. (1988): The Perseverance ultramafic complex, Western Australia: the product of a komatiite lava river. J. Petrol. 29, 305-331.

LESHER, C.M. \& KEAYS, R.R. (1995): Geochemistry of mineralised and barren komatiites from the Perseverance nickel deposit, Western Australia. Lithos 34, 209-234.

BAVINTON, O.A. (1979): Interflow Sedimentary Rocks from the Kambalda Ultramafic Sequence: their Geochemistry, Metamorphism, and Genesis. Ph.D. thesis, Australian National University, Canberra, Australia.

(1981): The nature of sulfidic sediments at Kambalda and their broad relationships with associated ultramafic rocks and nickel ores. Econ. Geol. 76, 16061628 .

\& KeAYs, R.R. (1978): Precious metal values from interflow sedimentary rocks from the komatiite sequence at Kambalda, Western Australia. Geochim. Cosmochim. Acta 42, 1151-1163.

\& TAYLOR, S.R. (1980): Rare-earth element geochemistry of Archean metasedimentary rocks from Kambalda, Western Australia. Geochim. Cosmochim. Acta 44, 639-648. 
BlEEKER, W. (1990): Evolution of the Thompson Nickel Belt and its Nickel Deposits, Manitoba. Ph.D. thesis, Univ. of New Brunswick, Fredericton, New Brunswick.

Brügmann, G.E., NAldrett, A.J., Asif, M., Lightfoot, P.C., GorbaCHEV, N.S. \& FEDORENKO, V.A. (1993): Siderophile and chalcophile metals as tracers of the evolution of the Siberian Trap in the Noril'sk region, Russia. Geochim. Cosmochim. Acta 57, 2001-2018.

Burnham, O.M., Lesher, C.M. \& Keays, R.R. (1999): Geochemistry of mafic-ultramafic complexes and associated basalts in the Raglan Block. In Komatiitic PeridotiteHosted Fe-Ni-Cu-(PGE) Sulphide Deposits in the Raglan Area, Cape Smith Belt, New Québec (C.M. Lesher, ed.). Mineral Exploration Research Centre, Laurentian University, Sudbury, Guidebook Ser. 2, 159-173.

CAmpbell, I.H. \& Barnes, S.J. (1984): A model for the geochemistry of the platinum-group elements in magmatic sulfide deposits. Can. Mineral. 22, 151-160.

\& NALDRETT, A.J. (1979): The influence of silicate:sulfide ratios on the geochemistry of magmatic sulfides. Econ. Geol. 74, 1503-1506.

Candela, P.A. \& Piccoli, P.M. (1998): Magmatic contributions to hydrothermal ore deposits: an algorithm (MVPart) for calculating the composition of a magmatic volatile phase. In Techniques in Hydrothermal Ore Deposits (J.P. Richards \& P.B. Larson, eds.). Rev. Econ. Geol. 10, 97-108.

Cowden, A., Donaldson, M.J., NAldREtT, A.J. \& CAMPBell, I.H. (1986): Platinum-group elements and gold in the komatiite-hosted $\mathrm{Fe}-\mathrm{Ni}-\mathrm{Cu}$ sulfide deposits at Kambalda, Western Australia. Econ. Geol. 81, 1226-1235.

\& RoBERTS, D.E. (1990): Komatiite hosted nickel sulphide deposits. In Geology of the Mineral Deposits of Australia and Papua New Guinea (F.E. Hughes, ed.). Australian Institution of Mining and Metallurgy, Melbourne, Australia (567-581).

\& WoOlRich, P. (1987): Geochemistry of the Kambalda iron-nickel sulfides: implications for models of sulfide-silicate partitioning. Can. Mineral. 25, 21-36.

Cumming, G.L. \& KRSTIC, D. (1991): Geochronology at the Namew Lake $\mathrm{Ni}-\mathrm{Cu}$ deposit, Flin Flon area, Manitoba, Canada: $\mathrm{a} \mathrm{Pb} / \mathrm{Pb}$ study of whole rocks and ore minerals. Can. J. Earth Sci. 28, 1328-1339.

Czamanske, G.K., Wooden, J.L., Zientek, M.L., Fedorenko, V.A., ZEN'Ko, T.E., Kent, J., KING, B.S.W., KNIGHT, R.J. \& SIEMS, D.F. (1994): Chemical and isotopic constraints on the petrogenesis of the Noril'sk-Talnakh ore-forming system. In Proceedings of the Sudbury-Noril'sk Symposium (P.C. Lightfoot \& A.J. Naldrett, eds.). Ontario Geol. Surv., Spec. Vol. 5, 313-341.

Dickin, A. (1995): Radiogenic Isotope Geology. Cambridge University Press, Cambridge, U.K.
Donnelly, T.H., Lambert, I.B., Oehler, D.Z., HallberG, J.A., Hudson, D.R., Smith, J.W., Bavinton, O.A. \& GoLDING, L. (1978): A reconnaissance study of stable isotope ratios in Archaean rocks from the Yilgarn Block, Western Australia. J. Geol. Soc. Aust. 24, 409-420.

DufFIELD, W.A. \& RuIZ, J. (1998): A model that helps explain Sr-isotope disequilibrium between feldspar phenocrysts and melt in large-volume silicic magma systems. $J$. Volcanol. Geotherm. Res. 87, 7-13.

DuKE, J.M. (1979): Computer simulation of the fractionation of olivine and sulfide from mafic ultramafic magmas. Can. Mineral. 17, 507-514.

(1986): Petrology and economic geology of the Dumont sill: an Archean Intrusion of komatiitic affinity in northwestern Quebec. Geol. Surv. Can., Econ. Geol. Rep. 35.

\& NALDRETT, A.J. (1978): A numerical model of the fractionation of olivine molten sulfide from komatiite magma. Earth Planet. Sci. Lett. 39, 255-266.

DuPRÉ, B. \& ARNDT, N.T. (1990): Pb isotopic compositions of Archean komatiites and sulfides. Chem. Geol. 85, 35-56.

ECKSTRAND, O.R. (1975): The Dumont serpentinite: a model for control of nickeliferous opaque assemblages by alteration reactions in ultramafic rocks. Econ. Geol. 70, 183-201.

Evans, D.M., Cowden, A. \& Barrett, R.M. (1989): Deformation and thermal erosion at the Foster nickel deposit, Kambalda - St. Ives, Western Australia. In Magmatic Sulphides - the Zimbabwe Volume (M.D. Prendergast \& M.J. Jones, eds.). Institution of Mining and Metallurgy, London, U.K. (215-220).

FAURE, G. (1986): Principles of Isotope Geology (second ed.). J. Wiley \& Sons, New York, N.Y.

Foster, J.G., LAMBert, D.D., Frick, L.R. \& MAAs, R. (1996): $\mathrm{Re}-\mathrm{Os}$ isotopic evidence for genesis of Archaean nickel ores from uncontaminated komatiites. Nature 382, 703-706.

Frost, K.M. \& Groves, D.I. (1989): Ocellar units in the Kambalda-Widgiemooltha komatiite sequence: evidence for sediment assimilation by komatiite lavas. In Magmatic Sulphides - the Zimbabwe Volume (M.D. Prendergast \& M.J. Jones, eds.). Institution of Mining and Metallurgy, London, U.K. (207-214).

Green, A.H. \& MelezhiK, V.A. (1999): Geology of the Pechenga ore deposits - a review with comments on oreforming processes. In Dynamic Processes in Magmatic Ore Deposits and their Application in Mineral Exploration (R.R. Keays, C.M. Lesher, P.C. Lightfoot \& C.E.G. Farrow, eds.). Geol. Assoc. Can., Short Course Notes 13, 287-328.

\& NALDRETT, A.J. (1981): The Langmuir volcanic peridotite-associated nickel deposits: Canadian equivalents of the Western Australian occurrences. Econ. Geol. 76, 1503-1523. 
GRESHAM, J.J. (1986): Depositional environments of volcanic peridotite-associated nickel sulfide deposits with special reference to the Kambalda Dome. In Geology and Metallogeny of Copper Deposits (G.H. Friedrich, A,D. Genkin, A.J. Naldrett, J.D. Ridge, R.H. Sillitoe \& F.M. Vokes, eds.). Springer-Verlag, Berlin, Germany (63-90).

\& Loftus-HiLls, G.D. (1981): The geology of the Kambalda nickel field, Western Australia. Econ. Geol. 76, 1373-1416.

GRINENKO, L.N. (1985): Sources of sulfur in the nickeliferous and barren gabbro-dolerite intrusions of the northwest Siberian platform. Int. Geol. Rev. 27, 695-708.

\& SMOL'KIN, V.F. (1991): Isotopic composition and content of sulphur in the ferropicrites and gabbro-wehrlites of the Pechenga zone. Geochemistry 9, 1250-1261.

Groves, D.I., Barrett, F.M. \& McQueEn, K.G. (1979): The relative roles of magmatic segregation, volcanic exhalation and regional metamorphism in the generation of volcanicassociated nickel ores of Western Australia. Can. Mineral. 17, 319-336.

\& KEAYS, R.R. (1979): Mobilization of ore-forming elements during alteration of dunites, Mt. Keith - Betheno, Western Australia. Can. Mineral. 17, 373-389.

Korkiakoski, E.A., McNaughton, N.J., Lesher, C.M. \& COWDEN, A. (1986): Thermal erosion by komatiites at Kambalda, Western Australia and the genesis of nickel ores. Nature 319, 136-139.

Hanski, E.J. (1992): Petrology of the Pechenga ferropicrites and co-genetic, Ni-bearing gabbro-wehrlite intrusions Kola Peninsula, Russia. Geol. Surv. Finland, Bull. 367.

HARRIS, P.G. (1957): Zone refining and the origin of potassic basalts. Geochim. Cosmochim. Acta 12, 195-208.

HEAmAn, L. \& LudDEn, J.N., eds. (1991): Applications of Radiogenic Isotope Systems to Problems in Geology. Mineral. Assoc. Can., Short Course Handbook 19.

Huppert, H.E., Sparks, R.S.J., TuRner, J.S. \& ARndT, N.T. (1984): Emplacement and cooling of komatiites. Nature 309, 19-22.

KeAYs, R.R. (1982): Palladium and iridium in komatiites and associated rocks: application to petrogenetic problems. In Komatiites (N.T. Arndt \& E.G. Nisbet, eds.). Allen and Unwin, London, U.K. (435-457).

(1995): The role of komatiitic and picritic magmatism and S-saturation in the formation of ore deposits. Lithos 34, 1-18.

\& LightFoot, P.C. (1999): The role of meteorite impact, source rocks, protores, and mafic magmas in the genesis of the Sudbury Ni-Cu-PGE sulphide ore deposits. In Dynamic Processes in Magmatic Ore Deposits and their
Application to Mineral Exploration (R.R. Keays, C.M. Lesher, P.C. Lightfoot \& C.E.G. Farrow, eds.). Geol. Assoc. Can., Short Course Notes 13, 195-250.

Ross, J.R. \& WoOlRICH, P. (1981): Precious metals in volcanic peridotite-associated nickel sulfide deposits in Western Australia. II. Distribution within the ores and host rocks in Kambalda. Econ. Geol. 76, 1645-1674.

LAhaye, Y. \& ARndT, N.T. (1996): Alteration of a komatiite flow from Alexo, Ontario, Canada. J. Petrol. 37, 12611284 .

Byerly, G., Chauvel, C., Fourcade, S. \& GRUAU, G. (1995): The influence of alteration on the trace-element and $\mathrm{Nd}$ isotopic compositions of komatiites. Chem. Geol. 126, 43-64.

Lambert, D.D., Foster, J.G., Frick, L.R., HoAtson, D.M. \& PuRvis, A.C. (1998a): Application of the Re-Os isotopic system to the study of Precambrian magmatic sulphide deposits of Western Australia. In The Application of Radiogenic Isotopes to the Study of Australian Ore Deposits (I. Campbell, D. Groves \& N. McNaughton, eds.). Aust. J. Earth Sci. 45, 265-284.

Li, Chusi \& Naldrett, A.J. (1999a): Re-Os isotopic systematics of the Voisey's Bay $\mathrm{Ni}-\mathrm{Cu}-\mathrm{Co}$ magmatic ore system, Labrador, Canada. In Geodynamics of Giant Magmatic Ore Systems (D.D. Lambert \& E.M. Ripley, eds.). Lithos 47, 69-88.

\& RIPLEY, E.M. (1999b): ReOs isotope geochemistry of magmatic sulfide ore systems. In Applications of Radiogenic Isotopes to Ore Deposit Research and Exploration (D.D. Lambert \& J. Ruiz, eds.). Rev. Econ. Geol. 12, 29-58.

\& ZIENTEK, M.L.

(1998b): Geodynamics of magmatic Cu-Ni-PGE sulfide deposits: new insights from the $\mathrm{Re}-\mathrm{Os}$ isotope system. Econ. Geol. 93, 121-136.

Frick, L.R., Foster, J.G., LI, CHUSI \& NALDRETT, A.J. (2000): Re-Os isotopic systematics of the Voisey's Bay $\mathrm{Ni}-\mathrm{Cu}-\mathrm{Co}$ magmatic sulfide system, Labrador, Canada. II. Implications for parental magma chemistry, ore genesis, and metal redistribution. Econ. Geol. 95, 867-888.

LEE, I. \& RIPLEY, E.M. (1995): Genesis of the Cu-Ni sulfide mineralization in the South Kawishiwi intrusion, Spruce Road area, Duluth Complex, Minnesota. Can. Mineral. 33, 723-743.

LESHER, C.M. (1983): Localization and Genesis of KomatiiteHosted $\mathrm{Fe}-\mathrm{Ni}-\mathrm{Cu}$ Sulphide Mineralization at Kambalda, Western Australia. Ph.D. dissertation, Univ. of Western Australia, Perth, Australia.

(1989): Komatiite-associated nickel sulfide deposits. In Ore Deposition Associated with Magmas (J.A. Whitney \& A.J. Naldrett, eds.). Rev. Econ. Geol. 4, 45-101. 
\& ARNDT, N.T. (1995): REE and Nd isotope geochemistry, petrogenesis, and volcanic evolution of contaminated komatiites at Kambalda, Western Australia. Lithos 34, 127-157.

\& GRoves, D.I. (1984): Genesis of komatiite-associated nickel sulphide deposits at Kambalda, Western Australia: a distal volcanic model. In Sulphide Deposits in Mafic and Ultramafic Rocks (D.L. Buchanan \& M.J. Jones, eds.). Institution of Mining and Metallurgy, London, U.K. (70-80).

Barnes, S.-J., Gillies, S.L. \& Ripley, E.M. (1999a): Ni-Cu-(PGE) sulphides in the Raglan Block. In Komatiitic Peridotite-Hosted $\mathrm{Fe}-\mathrm{Ni}-\mathrm{Cu}$-(PGE) Sulphide Deposits in the Raglan Area, Cape Smith Belt, New Québec (C.M. Lesher, ed.). Mineral Exploration Research Centre, Laurentian University (Sudbury), Guidebook Ser. 2, 177184

\& Burnham, O.M. (1999): Mass balance and mixing in dynamic ore-forming magmatic systems. In Dynamic Processes in Magmatic Ore Deposits and their Application in Mineral Exploration (R.R. Keays, C.M. Lesher, P.C. Lightfoot \& C.E.G. Farrow, eds.). Geol. Assoc. Can., Short Course Notes 13, 413-449.

KeAys, R.R., BARNes, S.J. \& Hulbert, L. (1999b): Geochemical discrimination of barren and mineralized komatiites in dynamic ore-forming magmatic systems. In Dynamic Processes in Magmatic Ore Deposits and their Application in Mineral Exploration (R.R. Keays, C.M. Lesher, P.C. Lightfoot \& C.E.G. Farrow, eds.). Geol. Assoc. Can., Short Course Notes 13, 451-477.

$\&$

(2001): Trace-element geochemistry and petrogenesis of barren and ore-associated komatiites. Can. Mineral. 39, 673-696.

\& CAMPBELl, I.H. (1993): Geochemical and fluid dynamic modeling of compositional variations in Archean komatiite-hosted nickel sulfide ores in Western Australia. Econ. Geol. 88, 804-816.

\& Charland, A. (1999): Geology of the Katinniq area. In Komatiitic Peridotite-Hosted Fe-Ni-Cu-(PGE) Sulphide Deposits in the Raglan Area, Cape Smith Belt, New Québec (C.M. Lesher, ed.). Mineral Exploration Research Centre, Laurentian University (Sudbury), Guidebook Ser. 2, 91-106.

\& GRoves, D.I. (1984): Geochemical and mineralogical criteria for the identification of mineralized komatiites in Archaean greenstone belts of Australia. In Petrology. Igneous and Metamorphic Rocks. VNU Science Press, Utrecht, The Netherlands (283-302).

$\&$ (1986): Controls on the formation of komatiite-associated nickel-copper sulfide deposits. In Geology and Metallogeny of Copper Deposits (G. Friedrich, A.D. Genkin, A.J. Naldrett, J.D. Ridge, R.H. Sillitoe \& F.M. Vokes, eds.). Springer-Verlag, Heidelberg, Germany (43-62).
Lee, R.F., Groves, D.I., Bickle, M.J. \& DonalDSON, M.J. (1981): Geochemistry of komatiites from Kambalda, Western Australia. I. Chalcophile element depletion - a consequence of sulfide liquid separation from komatiitic magmas. Econ. Geol. 76, 1714-1728.

\& RIPLEY, E.M. (1992): Sulfur isotope geochemistry of Proterozoic komatiitic peridotite-hosted $\mathrm{Fe}-\mathrm{Ni}-\mathrm{Cu}$ sulfide deposits, Cape Smith belt, New Québec. Geol. Soc. Am., Abstr. Programs 24(7), A62.

\& Stone, W.E. (1996): Exploration geochemistry of komatiites. In Igneous Trace Element Geochemistry: Applications for Massive Sulphide Exploration (D. Wyman, ed.). Geol. Assoc. Can., Short Course Notes 12, 153-204.

Thibert, F., Gillies, S.L., Stilson, C.M., THACKER, J.L. \& Williams, D.A. (1999c): Lithology and physical volcanology of komatiitic peridotite-gabbro complexes in the Raglan Block. In Komatiitic Peridotite-Hosted $\mathrm{Fe}-\mathrm{Ni}-\mathrm{Cu}-(\mathrm{PGE})$ Sulphide Deposits in the Raglan Area, Cape Smith Belt, New Québec (C.M. Lesher, ed.). Mineral Exploration Research Centre, Laurentian University (Sudbury), Guidebook Ser. 2, 43-60.

\& VICKER, P. (1999): Geology of the Donaldson area. In Komatiitic Peridotite-Hosted $\mathrm{Fe}-\mathrm{Ni}-\mathrm{Cu}-(\mathrm{PGE})$ Sulphide Deposits in the Raglan Area, Cape Smith Belt, New Québec (C.M. Lesher, ed.). Mineral Exploration Research Centre, Laurentian University (Sudbury), Guidebook Ser. 2, 143-149.

Li, Chusi, Lightfoot, P.C., Amelin, Y.V. \& Naldrett, A.J. (2000): Contrasting petrological and geochemical relationships in the Voisey's Bay and Mushuau intrusions, Labrador, Canada: implications for ore genesis. Econ. Geol. 95, 771-800.

\& NALDRETT, A.J. (2000): Melting reactions of gneissic inclusions with enclosing magma at Voisey's Bay, Labrador, Canada: implications with respect to ore genesis. Econ. Geol. 95, 801-814.

Lightfoot, P.C. \& NAldRetT, A.J. (1999): Geological and geochemical relationships in the Voisey's Bay intrusion, Nain plutonic suite, Labrador, Canada. In Dynamic Processes in Magmatic Ore Deposits and their Application in Mineral Exploration (R.R. Keays, C.M. Lesher, P.C. Lightfoot \& C.E.G. Farrow, eds.). Geol. Assoc. Can., Short Course Notes 13, 1-30.

Gorbachev, N.S., Fedorenko, V.A., Hawkesworth, C.J., Hergt, J. \& Doherty, W. (1994): Chemostratigraphy of Siberian Trap lavas, Noril'sk district: implications for the source of flood basalt magmas and their associated $\mathrm{Ni}-\mathrm{Cu}$ mineralization. In Proc. SudburyNoril'sk Symp. (P.C. Lightfoot \& A.J. Naldrett, eds.). Ontario Geol. Surv., Spec. Vol. 5, 283-312.

LuCK, J.-M. \& ALLÈGRE, C.J. (1984): ${ }^{187}$ Re/ $/{ }^{187}$ Os investigation in sulfide from Cape Smith komatiite. Earth Planet. Sci. Lett. 68, 205-208. 
\& ARNDT, N.T. (1985): Re/Os isochron for Archean komatiite from Alexo, Ontario. Terra Cognita 5, 323 (abstr.).

MAIER, W.D., BARnes, S.-J. \& DE WAal, S.A. (1998): Exploration for magmatic $\mathrm{Ni}-\mathrm{Cu}-\mathrm{PGE}$ sulphide deposits: a review of recent advances in the use of geochemical tools and their application to some South African ores. S. Afr. J. Geol. 101, 237-253.

Mainwaring, P.R. \& NAldRetT, A.J. (1977): Country-rock assimilation and the genesis of $\mathrm{Cu}-\mathrm{Ni}$ sulfides in the Water Hen intrusion, Duluth Complex, Minnesota. Econ. Geol. 72, 1269-1284.

MAtHeZ, E.A. (1999): On factors controlling the concentrations of platinum group elements in layered intrusions and chromitites. In Dynamic Processes in Magmatic Ore Deposits and their Application in Mineral Exploration (R.R. Keays, C.M. Lesher, P.C. Lightfoot \& C.E.G. Farrow, eds.). Geol. Assoc. Can., Short Course Notes 13, 251-286.

McNaughton, N.J., Frost, K.M. \& Groves, D.I. (1988): Ground melting and ocellar komatiites: a lead isotopic study at Kambalda, Western Australia. Geol. Mag. 125, 285-295.

Melezhik, V.A., Hudson-Edwards, K.A., Green, A.H. \& GrinenKo, L.I. (1994): The Pechenga area, Russia. 2. Nickel-copper deposits and related rocks. Trans. Inst. Mining Metall., Sect. B, Appl. Earth Sci. 103, 146-161.

Menard, T., Lesher, C.M., Stowell, H.H., Price, D., Pickell, J.R., ONSTOtT, T.C. \& Hulbert, L. (1996): Geology, genesis, and metamorphic history of the Namew Lake Fe-Ni$\mathrm{Cu}-\mathrm{PGE}$ deposit, Manitoba. Econ. Geol. 91, 1394-1413.

Ridgway, C.K., Stowell, H.H. \& Lesher, C.M. (1999): Geochemistry and textures of metasomatic combs and orbicules in ultramafic rocks, Namew Lake, Manitoba. Can. Mineral. 37, 431-442.

NALDRETT, A.J. (1981): Nickel sulfide deposits: classification, composition, and genesis. Econ. Geol., 75th Anniv. Vol., 628-685.

(1989): Magmatic Sulfide Deposits. Oxford University Press, New York, N.Y.

(1999): World-class Ni-Cu-PGE deposits: key factors in their genesis. Mineral. Deposita 34, 227-240.

\& BARNES, S.-J. (1986): The behavior of platinum group elements during fractional crystallization and partial melting with special reference to the composition of magmatic sulfide ores. Fortschr. Mineral. 64, 113-133.

, Fedorenko, V.A., Asif, M., Lin, S., Kunilov, V.I., Stekhin, A.I., Lightfoot, P.C. \& Gorbachev, N.S. (1996): Controls on the compositions of Ni-Cu sulfide deposits as illustrated by those at Noril'sk, Siberia. Econ. Geol. 91, 751-773.
Lightfoot, P.C., Kunilov, V.I., Gorbachev, N.S., DoherTy, W. \& Johan, Z. (1995): Ni$\mathrm{Cu}-\mathrm{PGE}$ deposits of the Noril'sk region, Siberia: their formation in conduits for flood basalt volcanism. Trans. Inst. Mining Metall., Sect. B, Appl. Earth Sci. 104, 18-36.

Hoffman, E.L., Green, A.H., Chou, Chen-Lin, NALDRETT, S.R. \& Alcock, R.A. (1979): The composition of Ni-sulfide ores, with particular reference to their content of PGE and Au. Can. Mineral. 17, 403-415.

\& LightFoot, P.C. (1999): Ni-Cu-PGE deposits of the Noril'sk region, Siberia: their formation in conduits for flood basalt volcanism. In Dynamic Processes in Magmatic Ore Deposits and their Application in Mineral Exploration (R.R. Keays, C.M. Lesher, P.C. Lightfoot \& C.E.G. Farrow, eds.). Geol. Assoc. Can., Short Course Notes 13, 195-250.

Fedorenko, V.A., Doherty, W. \& GoRBACHEV, N.S. (1992): Geology and geochemistry of intrusions and flood basalts of the Noril'sk region, USSR, with implications for the origin of the $\mathrm{Ni}-\mathrm{Cu}$ ores. Econ. Geol. 87, 975-1004.

Pessaran, R., Asif, M. \& Li, Chusi (1994): Compositional variation in the Sudbury ores and prediction of the proximity of footwall copper-PGE orebodies. In Proc. Sudbury-Noril'sk Symp. ( P.C. Lightfoot \& A.J. Naldrett, eds.). Ontario Geol. Surv., Spec. Vol. 5, 133-143.

RAo, B.V. \& Evensen, N.M. (1986): Contamination at Sudbury and its role in ore formation. In Metallogeny of Basic and Ultrabasic Rocks (M.J. Gallagher, R.A. Ixer, C.R. Neary \& H.M. Prichard, eds.). Institution of Mining and Metallurgy, London, U.K. (75-91).

Онмото, Н. (1986): Stable isotope geochemistry of ore deposits. In Stable Isotopes in High Temperature Geological Processes (J.W. Valley, H.P. Taylor, Jr. \& J.R. O’Neil, eds.). Rev. Mineral. 16, 491-559.

Perring, C.S., Barnes, S.J. \& Hill, R.E.T. (1995): The physical volcanology of Archean komatiite sequences from Forrestania, Southern Cross Province, Western Australia. Lithos 34, 189-207.

$\&$ (1996): Geochemistry of komatiites from Forrestania, Southern Cross Province, Western Australia: evidence for crustal contamination. Lithos 37, 181-197.

Pfann, W.G. (1952): Principles of zone melting. Trans. Am. Inst. Mining Engineering 194, 747-753.

Poulson, S.R. \& Онмото, H. (1989): Devolatilization equilibria in graphite-pyrite-pyrrhotite bearing pelites with application to magma pelite interaction. Contrib. Mineral. Petrol. 101, 418-425.

RIPLEY, E.M. (1981): Sulfur isotopic studies of the Dunka Road $\mathrm{Cu}-\mathrm{Ni}$ deposit, Duluth Complex, Minnesota. Econ. Geol. 76, 610-620. 
(1986a): Application of stable isotopic studies to problems of magmatic sulfide ore genesis with special reference to the Duluth Complex, Minnesota. In Geology and Metallogeny of Copper Deposits (G.H. Friedrich, A.D. Genkin, A.J. Naldrett, J.D. Ridge, R.H. Sillitoe \& F.M. Vokes, eds.). Springer-Verlag, Berlin, Germany (25-42).

(1986b): Origin and concentration mechanisms of copper and nickel in Duluth Complex sulfide zones - a dilemma. Econ. Geol. 81, 974-978.

(1990): Se/S ratios of the Virginia Formation and $\mathrm{Cu}-\mathrm{Ni}$ sulfide mineralization in the Babbitt area, Duluth Complex, Minnesota. Econ. Geol. 85, 1935-1940.

\& Alawi, J.A. (1988): Petrogenesis of pelitic xenoliths at the Babbitt $\mathrm{Cu}-\mathrm{Ni}$ deposit, Duluth Complex, Minnesota. Lithos 21, 143-159.

\& AL-JASSAR, T.J. (1987): Sulfur and oxygen isotopic studies of melt - country rock interaction, Babbitt $\mathrm{Cu}-$ Ni deposit, Duluth Complex, Minnesota. Econ. Geol. 82, 87-107.

Butler, B.K. \& TAIB, N.I. (1992): Effects of devolatilization on the hydrogen isotopic composition of pelitic rocks in the contact aureole of the Duluth Complex, northeastern Minnesota, U.S.A. Chem. Geol. (Isotope Geosci. Sect.) 102, 185-197.

, LAMBERT, D.D. \& FRICK, L.R. (1999a): Re-Os, Sm$\mathrm{Nd}$, and $\mathrm{Pb}$ isotopic constraints on mantle and crustal contributions to magmatic sulfide mineralization in the Duluth Complex. Geochim. Cosmochim. Acta 62, 3349-3365.

PARK, Y.-R., Li, ChUSI \& NALdRETT, A.J. (1999b): Sulfur and oxygen isotopic evidence of country rock contamination in the Voisey's Bay Ni-Cu-Co deposit, Labrador, Canada. In Geodynamics of Giant Magmatic Ore Systems (D.D. Lambert \& E.M. Ripley, eds.). Lithos 47, 5368 .

$$
\&
$$
(2000): Oxygen isotope studies of the Voisey's Bay $\mathrm{Ni}-\mathrm{Cu}-\mathrm{Co}$ deposit, Labrador, Canada. Econ. Geol. 95, 831-844.

\& TAIB, N.I. (1989): Carbon isotopic studies of metasedimentary and igneous rocks at the Babbitt $\mathrm{Cu}-\mathrm{Ni}$ deposit, Duluth Complex, Minnesota, U.S.A. Chem. Geol. (Isotope Geosci. Sect.) 73, 319-342.

Ross, J.R. \& KEAYs, R.R. (1979): Precious metals in volcanictype nickel sulfide deposits in Western Australia. I. Relationship with the composition of the ores and their host rocks. Can. Mineral. 17, 417-435.

SAmbridge, M. \& LAMBeRT, D.D. (1997): Propagating errors in decay equations: Examples from the Re-Os isotopic system. Geochim. Cosmochim. Acta 61, 3019-3024.

Seccombe, P.K., Groves, D.I., Marston, R.J. \& Barrett, F.M. (1981): Sulfide paragenesis and sulfur mobility in Fe$\mathrm{Ni}-\mathrm{Cu}$ sulfide ores at Lunnon and Juan Main shoots,
Kambalda: textural and sulfur isotopic evidence. Econ. Geol. 76, 1675-1685.

ShimaZaKi, H. \& MaCLean, W.H. (1976): An experimental study on the partition of zinc and lead between silicate and sulfide liquids. Mineral. Deposita 11, 125-132.

ShIREY, S.B. \& BARNES, S.-J. (1994): Re-Os and Sm-Nd isotopic constraints on basaltic komatiitic volcanism and magmatic sulphide formation in the Cape Smith foldbelt, Quebec. Mineral. Mag. 58A, $835-836$.

\& WaLker, R.J. (1995): Carius tube digestion for low-blank rhenium-osmium analysis. Anal. Chem. 67, 2136-2141.

Stilson, C.M., Vicker, P. \& Lesher, C.M. (1999): Geology of the Boundary area. In Komatiitic Peridotite-Hosted Fe$\mathrm{Ni}-\mathrm{Cu}-(\mathrm{PGE})$ Sulphide Deposits in the Raglan Area, Cape Smith Belt, New Québec (C.M. Lesher, ed.). Mineral Exploration Research Centre, Laurentian University (Sudbury), Guidebook Ser. 2, 133-142.

Stone, W.E. \& Masterman, E.E. (1998): Kambalda nickel deposits. In Geology of Australian and Papua New Guinean Mineral Deposits (D.A. Berkman \& D.H. Mackenzie, eds.). Australian Institution of Mining and Metallurgy, Melbourne, Australia (347-356).

TAYLOR, H.P., JR. (1997): Oxygen and hydrogen isotope relationships in hydrothermal mineral deposits. In Geochemistry of Hydrothermal Ore Deposits (H.L. Barnes, ed.; third edition). John Wiley \& Sons, New York, N.Y. (229-302).

ThéRIAUlt, R.D. \& BARnES, S.-J. (1998): Compositional variations in $\mathrm{Cu}-\mathrm{Ni}-\mathrm{PGE}$ sulfides of the Dunka Road deposit, Duluth Complex, Minnesota: the importance of combined assimilation and magmatic processes. Can. Mineral. 36, 869-886.

\& Severson, M. (2000): Origin of $\mathrm{Cu}-$ Ni-PGE sulfide mineralization in the Partridge River Intrusion, Duluth Complex, Minnesota. Econ. Geol. 95, 929943.

Tyson, R.M. \& Chang, L.L.Y. (1984): The petrology and sulfide mineralization of the Partridge River troctolite, Duluth Complex, Minnesota. Can. Mineral. 22, 23-38.

WALKer, R.J., Morgan, J.W., HANSKI, E.J. \& SMOL'KIN, V.F. (1994a): The role of the Re-Os system in the study of magmatic sulfide ores: a tale of three ores. In Proc. SudburyNoril'sk Symp. (P.C. Lightfoot \& A.J. Naldrett, eds.). Ontario Geol. Surv., Spec. Vol. 5, 343-355. $\&$ (1997): Re-Os systematics of Early Proterozoic ferropicrites, Pechenga Complex, northwestern Russia: evidence for ancient ${ }^{187} \mathrm{Os}-$ enriched plumes. Geochim. Cosmochim. Acta 61, 31453160 .

Horan, M.F., Czamanske, G.K., Krogstad, E.J., Fedorenko, V.A. \& Kunilov, V.E. 
(1994b): Re-Os isotopic evidence for an enriched-mantle source for the Noril'sk-type, ore-bearing intrusions, Siberia. Geochim. Cosmochim. Acta 58, 4179-4197.

Naldrett, A.J., Li, Chusi \& Fasset, J.D. (1991): Re-Os isotope systematics of $\mathrm{Ni}-\mathrm{Cu}$ sulfide ores, Sudbury Igneous Complex, Ontario: evidence for a major crustal component. Earth Planet. Sci. Lett. 105, 416429.

Williams, D.A., Kerr, R.C. \& Lesher, C.M. (1998): Emplacement and erosion by Archean komatiite lava flows at Kambalda: revisited. J. Geophys. Res. 103, 27533-27549. $\&$ (1999a): Thermal and fluid dynamics of komatiitic lavas associated with magmatic $\mathrm{Fe}-$ $\mathrm{Ni}-\mathrm{Cu}-(\mathrm{PGE})$ sulphide deposits. In Dynamic Processes in
Magmatic Ore Deposits and their Application in Mineral Exploration (R.R. Keays, C.M. Lesher, P.C. Lightfoot \& C.E.G. Farrow, eds.). Geol. Assoc. Can., Short Course Notes 13, 367-412.

$\&$

(1999b): Thermal erosion modeling of lava channels in the Raglan Block. In Komatiitic Peridotite-Hosted $\mathrm{Fe}-\mathrm{Ni}-\mathrm{Cu}-(\mathrm{PGE})$ Sulphide Deposits in the Raglan Area, Cape Smith Belt, New Québec (C.M. Lesher, ed.). Mineral Exploration Research Centre, Laurentian University (Sudbury), Guidebook Ser. 2, 174176

Received December 15, 1999, revised manuscript accepted April 15, 2001. 


\section{Appendix: Stratigraphic Mass-Balance in the Ore Environment at Kambalda}

The stratigraphy of the ore environment at Kambalda is relatively well constrained from systematic diamond drilling and detailed stratigraphic studies (Fig. 1). The ores occur at or near the basal contact of the Kambalda Komatiite Formation within or above linear embayments in footwall metabasalts, and are hosted by thick (up to $100 \mathrm{~m}$ ), highly magnesian (40-45\% MgO, $\mathrm{Fo}_{91-94)}$ mesocumulate komatiite units that grade laterally into thinner (10-30 m), less magnesian (35-40\% $\mathrm{MgO}$, up to $\mathrm{Fo}_{89-91}$ ) orthocumulate komatiite units. Although the embayments and ore zones are deformed, the stratigraphic relationships within the basalts suggest that the embayments were volcanic topographic features (Lesher et al. 1984, Evans et al. 1989, Lesher 1989). The chemical composition, textures, and geometry of the host units suggest that they are channelized sheetflows (Lesher et al. 1984, Lesher 1989, Lesher \& Arndt 1995). The flanking sheet-flow facies of the host units are underlain and separated by interflow metasedimentary rocks, but these rocks are normally absent beneath and above the ore zones and lava channels. Although the eruptive sites have not been identified, individual lava-channels are at least $1.5 \mathrm{~km}$ in length, the mineralized lava-channel system is at least $50 \mathrm{~km}$ in length, and the ore-forming system may have extended for tens of $\mathrm{km}$ upstream and downstream from the present locations of the ores zones (Lesher et al. 1984, Lesher 1989, Williams et al. 1998, 1999a).

The siliceous, sulfidic interflow metasedimentary rocks along the basal contact outside of the ore zones (Fig. 1) are up to $3 \mathrm{~m}$ thick at distances up to $500 \mathrm{~m}$ from the ore zones (Bavinton 1979). They thin and include an increasing proportion of "green chloritic metasediments" toward the ore zones, and are absent within a "barren void zone" that is in some cases wider and in some cases narrower than the ore shoots. As they are very fine-grained, seem to have contained a predominantly chemical component, are regionally extensive, and do not exhibit any evidence of having been preferentially deposited in the thicker areas (Bavinton $1979,1981)$, it is reasonable to assume that they were originally $\sim 3 \mathrm{~m}$ thick in the ore zones. If so, then we estimate that $\sim 36 \mathrm{wt} \%$ of the sediment has been completely preserved, $\sim 6 \mathrm{wt} \%$ has been partially preserved as restite, and $\sim 58 \mathrm{wt} \%$ is missing and inferred to have been thermomechanically eroded (Lesher et al. 1984). This calculation differs from that of Gresham (1986), who used the average present (preserved) thickness of the sediment $(\sim 1 \mathrm{~m})$, not the original thickness of the sediment $(\sim 3 \mathrm{~m})$.

The metasediments contain an average of $\sim 7.6 \mathrm{wt} \%$ $\mathrm{S}$ (Bavinton 1979, 1981) and therefore $20 \mathrm{wt} \%$ sulfides. Geochemical mass-balance calculations using the data in Table 3 indicate that the metasedimentary rocks also contain $\sim 10 \mathrm{wt} \%$ mafic components equivalent in composition to the chloritized sediments and $\sim 70 \mathrm{wt} \%$ felsic components equivalent in composition to the felsic ocellites (Lesher et al. 1999b). Thus, approximately four mass units of xenomelt would have been produced for every mass unit of sulfide derived from the sediment. Some of this material is locally preserved as felsic ocellites (McNaughton et al. 1988, Frost \& Groves 1989), but most would have been miscible and rapidly mixed into the komatiitic lava (see discussion by Lesher et al. 1984, Lesher \& Campbell 1993, Lesher $\&$ Arndt 1995). The mafic component of the sediment also seems to be locally preserved as the chloritic sediments that flank the lava channels, but it, too, would have been largely miscible and mixed into the lava. The original sediment would have been unconsolidated and would have comprised a mixture of seawater, siliceous oozes, sulfide oozes, and minor fine-grained continentally derived detritus (Bavinton 1979), which would have had densities different than those assumed here, but the mass proportions would not have been greatly different. If we assume that two mass units of olivine crystallize for each mass unit of sediment assimilated (i.e., A:FC 0.5: Lesher \& Arndt 1995), then the average mass-proportions of sulfide : xenomelt : residue : solid would have been $1: 4: 0.5: 7$.

The original widths and thicknesses of the ore shoots at Kambalda vary considerably and comprise variable proportions of massive, net-textured, and disseminated sulfides (Gresham \& Loftus-Hills 1981). The ore-localizing embayments are 2-30 $\mathrm{m}$ deep and 50-250 $\mathrm{m}$ wide (Lesher 1989). The ores range from less than $1 \mathrm{~m}$ to more than $20 \mathrm{~m}$ in thickness, but average $\sim 1 \mathrm{~m}$ on a $100 \%$ sulfide basis, and have been estimated to cover $\sim 10 \%$ of the basal contact (Lesher et al. 1981).

The mass balances of the different components in the ore-forming system can be estimated from a simplified block-diagram that simulates the relative abundances of these various stratigraphic elements prior to and after emplacement of the host unit (Fig. A1). These calculations suggest that there is a deficiency of sulfides in the ore zones compared to the amount that should have been present in the sediments. Only if the sediments were less than $1.3 \mathrm{~m}$ thick ( $c f$. Gresham 1986) would there be a deficiency in $\mathrm{S}$, but even if the sediments were thinner, the shortfall in $\mathrm{S}$ could easily have been derived from sediments upstream from the deposits, where thermal erosion should have been even greater (see discussion by Lesher et al. 1984, Lesher \& Groves 1986, Lesher 1989, Lesher \& Campbell 1993, Williams et al. 1998, 1999a). 


\begin{tabular}{|c|c|c|c|c|c|c|c|c|c|}
\hline $\mathrm{S}$ & $\mathrm{S}$ & $\mathrm{S}$ & $\mathrm{S}$ & $\mathrm{S}$ & & $\mathrm{S}$ & $\mathrm{S}$ & $\mathrm{S}$ & $\mathrm{S}$ \\
\hline S & S & $\mathrm{S}$ & $\mathrm{S}$ & $\mathrm{S}$ & $\mathrm{S}$ & $\mathrm{S}$ & $\mathrm{S}$ & $\mathrm{S}$ & $\mathrm{S}$ \\
\hline S & $\mathrm{S}$ & $\mathrm{S}$ & $\mathrm{S}$ & $\mathrm{S}$ & $\mathrm{S}$ & $\mathrm{S}$ & $\mathrm{S}$ & $\mathrm{S}$ & $\bar{S}$ \\
\hline & & & & & $\mathrm{S}$ & & & & \\
\hline & & & & & $\mathrm{S}$ & & & & \\
\hline & & & & & & & & & \\
\hline & & & & & & & & & \\
\hline
\end{tabular}

\begin{tabular}{|c|c|c|c|c|c|c|c|c|c|}
\hline $\mathrm{K}$ & $\mathrm{K}$ & $\mathrm{K}$ & $\mathrm{K}$ & $\mathrm{K}$ & $\mathrm{K}$ & $\mathrm{K}$ & $\mathrm{K}$ & $\mathrm{K}$ & $\mathrm{K}$ \\
\hline $\mathrm{K}$ & $\mathrm{K}$ & $\mathrm{K}$ & $\mathrm{K}$ & $\mathrm{K}$ & $\mathrm{K}$ & $\mathrm{K}$ & $\mathrm{K}$ & $\mathrm{K}$ & $\mathrm{K}$ \\
\hline $\mathrm{K}$ & $\mathrm{K}$ & $\mathrm{K}$ & $\mathrm{K}$ & $\mathrm{K}$ & $\mathrm{K}$ & $\mathrm{K}$ & $\mathrm{K}$ & $\mathrm{K}$ & $\mathrm{K}$ \\
\hline $\mathrm{K}$ & $\mathrm{K}$ & $\mathrm{K}$ & $\mathrm{K}$ & $\mathrm{K}$ & $\mathrm{K}$ & $\mathrm{K}$ & $\mathrm{K}$ & $\mathrm{K}$ & $\mathrm{K}$ \\
\hline $\mathrm{S}$ & (K) & $(\mathrm{K})$ & (K) & (K) & $\mathrm{K}$ & (K) & (K) & (K) & (K) \\
\hline $\mathrm{S}$ & $\mathrm{s}$ & (K) & (K) & (K) & (K) & (K) & (K) & $\mathrm{S}$ & $\mathrm{S}$ \\
\hline $\mathrm{S}$ & $\mathrm{S}$ & $\mathrm{S}$ & $\mathrm{R}$ & (K) & (K) & $\mathrm{R}$ & $\mathrm{S}$ & $\mathrm{S}$ & $\mathrm{S}$ \\
\hline & & & & & (K) & & & & \\
\hline & & & & & N15: & & & & \\
\hline & & & & & & & & & \\
\hline & & & & & & & & & \\
\hline $\mathrm{R}$ & \multicolumn{2}{|c|}{ Mafic Sediment (restite) } & $\mathrm{K}$ & Komatiite & & & \multicolumn{2}{|c|}{ Cell Thickness } & $1 \mathrm{~m}$ \\
\hline & \multicolumn{2}{|c|}{ Ni-Cu-(PGE) Sulfide } & (K) & Komatiite & nt mi & & \multicolumn{2}{|c|}{ Cell Width } & $100 \mathrm{~m}$ \\
\hline & \multicolumn{2}{|l|}{ Basalt } & $\mathrm{S}$ & Siliceous, & Sedi & & \multicolumn{2}{|c|}{ Third Dimension } & $1000 \mathrm{~m}$ \\
\hline
\end{tabular}

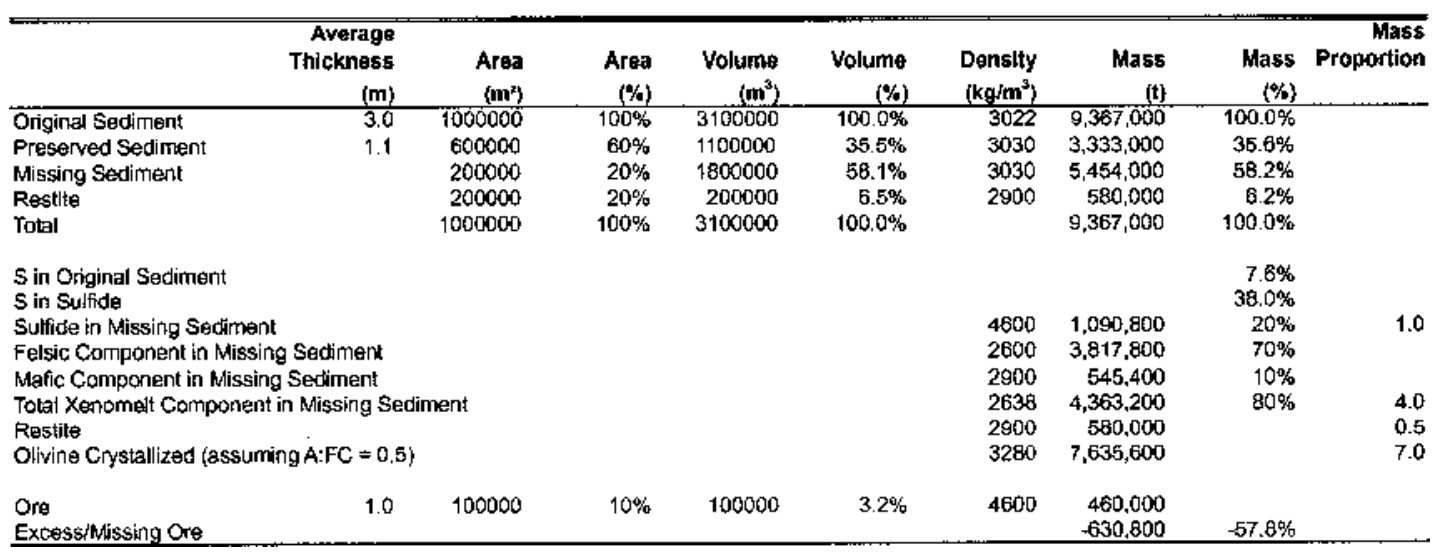

FIG. A1. Mass-balance model for a Kambalda ore shoot. The upper block diagram represents the inferred original distribution of sediment on the footwall basalt contact, whereas the lower block diagram represents the distribution of ore and sediment after emplacement of the basal komatiite unit (not all of komatiite unit is shown). The mass balances are summarized in the table, assuming that each cell is $100 \mathrm{~m}$ wide, $1 \mathrm{~m}$ thick, and extends $1000 \mathrm{~m}$ in the third dimension; changing these numbers or using smaller cells to simulate gradations in thickness across the section does not change the relative proportions of the components. As discussed in the text, some of the parameters (e.g., original maximum thickness of sediment, final average thickness of sediment, average thickness of ore, area of contact covered by ore) are relatively well constrained, whereas other parameters (e.g., area and thickness of residue) are less well constrained. However, the results provide an order-of-magnitude estimate of the relative proportion of components in the ore-forming system and a reasonable basis for parameterizing the models. 